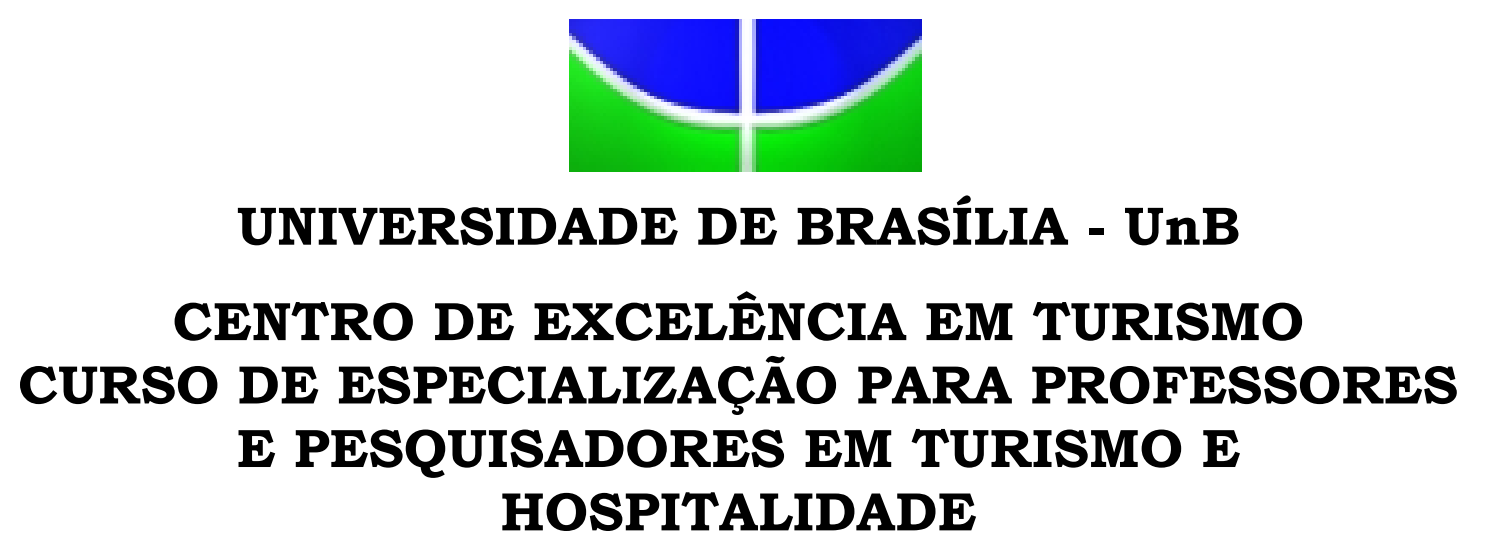

\title{
TURISMO EM BRASÍLIA PARA PORTADORES DE NECESSIDADES ESPECIAIS
}

\section{MARIA LÚCIA DE SÁ CRISTOFIDIS}

Orientador. Prof. Sandra Vivacqua Von

Tiesenhansen

Monografia apresentada ao Centro
de Excelência em Turismo da
Universidade de Brasilia como
requisito parcial para a obtenção
do certificado de especialista
em_

BRASÍLIA

2003 


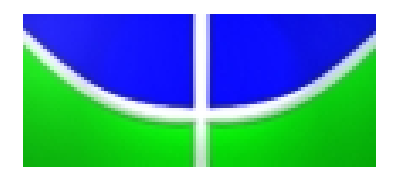

\author{
UNIVERSIDADE DE BRASÍLIA - UnB \\ CENTRO DE EXCELÊNCIA EM TURISMO \\ CURSO DE ESPECIALIZAÇÃO PARA PROFESSORES \\ E PESQUISADORES EM TURISMO E \\ HOSPITALIDADE
}

MARIA LÚCIA DE SÁ CRISTOFIDIS

\title{
TURISMO EM BRASÍLIA PARA PORTADORES DE NECESSIDADES ESPECIAIS
}




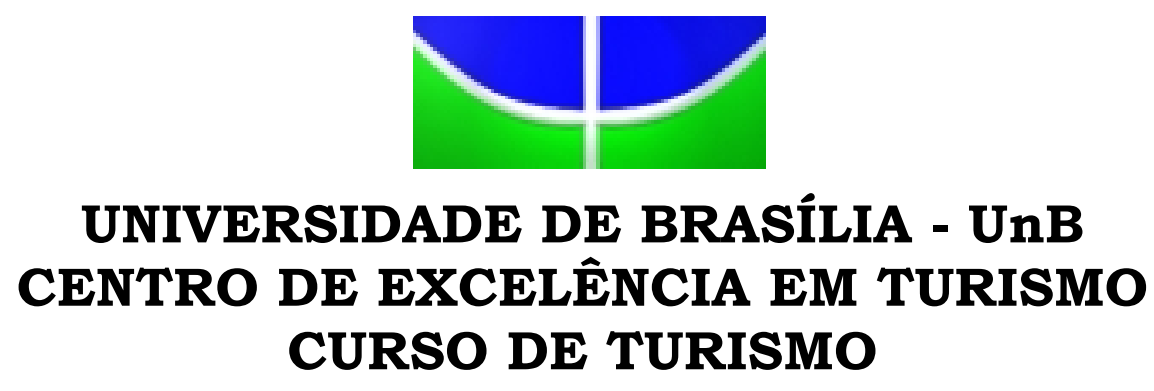

TURISMO EM BRASÍLIA PARA PORTADORES DE NECESSIDADES ESPECIAIS

MARIA LÚCIA DE SÁ CRISTOFIDIS

Prof. Sandra Vivacqua Von Tiensenhansen

Orientadora

Membro da Banca Examinadora

Membro da Banca Examinadora 
"Os rios são caminhos que andam e que nos levam aonde queremos ir". Blaise Pascal 
Dedico este trabalho:

A Deus, pelo dom da vida. Ao meu querido esposo, João Cristofidis, pelo apoio e carinho.

Aos meus filhos, Yannes, Carolina e Livia, pelo amor e carinho que me dedicam e por terem sido meus melhores modelos. 
A minha orientadora, professora Sandra Vivacqua Von Tiesenhausen, pela leitura dos rascunhos deste trabalho, o que resultou numa série de importantes sugestões para melhorar sua qualidade. Pela atenção, por transmitir seus ensinamentos e experiências que contribuíram para a elaboração desta monografia.

A coordenadora do Curso de Especialização para Professores e Pesquisadores em Turismo e Hospitalidade, Tânia Siqueira Montoro e a todos aqueles que colaboraram direta ou indiretamente para a realização deste trabalho, meus sinceros agradecimentos. 



\section{$E$}

\section{INTRODUÇÃO}

Este presente trabalho monográfico dedica-se ao desenvolvimento do turismo para pessoas com necessidades especiais. Levando em consideração que essa fatia da sociedade representa não mais uma minoria, mas um percentual considerável. Embora a Constituição Federal seja norteada pelo princípio de que o direito de livre acesso ao meio físico e de livre locomoção é parte indissociável dos Direitos Humanos, falta a visão da obrigatoriedade, bem como uma ligação entre a Lei e os já existentes parâmetros estabelecidos pelas normas técnicas de acessibilidades da NBR 9050/1994, feitas pela ABNT. Essas normas visam a proporcionar às pessoas portadoras de necessidades especiais, e àquelas com capacidades ambulatória reduzida, condições adequadas e seguras de acessibilidade autônoma aos pontos turísticos de Brasília.

Trata-se de uma tomada de consciência desde distintos âmbitos com um propósito dobrado: por um lado, permitir uma melhor qualidade de vida ao indivíduo com necessidades especiais, facilitando sua integração a vida comunitária em todos os âmbitos, e por outro, não descuidar deste segmento do mercado turístico. É de grande relevância para Brasília, como capital do Brasil, desenvolver na cidade o turismo para esta parte da população que tanto sofre com a exclusão social, com o fato de sobreviver com suas limitações, e ainda assim não terem acesso ao turismo como o restante da população.

Existe a necessidade de trabalhar com todos os setores envolvidos no campo turístico para converter Brasília em um destino de acessibilidade às pessoas com 
necessidades especiais. Brasília sendo o ponto de partida, tornando-se exemplo para o restante do país, e dando a chance a um diferente, enquanto portador de necessidades especiais, de se tornar um igual através da conquista da auto-estima, da autonomia e da interação com o mundo do turismo. Por esta perspectiva, algumas amostragens deste movimento de conquistas constam desta monografia em forma de depoimentos e entrevistas que informam e delineiam sugestões e solicitações de pessoas com necessidades especiais, enquanto turistas no território brasileiro e enquanto moradores da capital do país. A partir destes variados testemunhos, com ênfase no aspecto da acessibilidade, a autora traçou os itinerários turísticos de Brasília, evidenciando o propósito de seu trabalho: a principal atração de Brasília é ela mesma.

Cumpre agora, ao profissional do turismo, saber beneficiar-se destas condições altamente favoráveis aos turistas portadores de necessidades especiais em Brasília, possibilitando-Ihes, mediante ações afirmativas como as aqui apresentadas, o direito de vivenciarem como iguais, da cidade de poder e prazer e que propícia todas as modalidades de turismo, que tem cenários da história recente do país, monumentos que são obras de arte e, sobretudo, uma arquitetura de superquadras que por si só, valem passeios e pacotes turísticos convencionais que não se esgotam.

Os portadores de necessidades especiais representam $2 \%$ da população. Só na cidade de São Paulo, esse número gira em torno de 300 mil pessoas, segundo dados da Organização Mundial de Saúde. Nos últimos anos, tem-se notado uma preocupação maior com as questões da acessibilidade dessas pessoas aos espaços, sejam eles de uso público ou não, em especial o acesso aos setores que compõem o mundo do turismo.

Para o pleno desenvolvimento de um individuo, necessita-se potencializar principalmente três variáveis: a confiança em si mesmo, a independência e o sentimento de solidariedade nas distintas fases de seu desenvolvimento (individual, grupal ou social). 
Se a integração plena está longe de ser realidade para a maioria dos cidadãos do nosso país, o que dizer então das pessoas portadoras de deficiência... Mas, quando o impedimento tem por base barreiras físicas, superáveis com certa facilidade, é urgente modificarmos esta situação, fazendo as adaptações necessárias em edifícios, espaços e equipamentos urbanos.

As pessoas com necessidades especiais constituem um segmento do mercado turístico que o visionário André Leclerc, Director do KEROUL - Tourisme pour Personnes a Capacite Physique Restreinte-soube apreciar já ha quinze anos ao ser um dos primeiros em falar do turismo sem barreiras, como meio de conscientização que permitiria a integração deste setor da população também em outros âmbitos da vida comunitária. Sua postura é comparável a do Dr. Ludwig Guttmann, que foi o precursor do esporte para pessoas com necessidades especiais, e lidava com pacientes afetados de paralisias devido a lesões da medula espinhal, e que viu no esporte um modo de ajudar a recuperação do paciente, e de combater o tédio da vida hospitalar. Seu empreendimento há dado lugar aos atuais jogos Olímpicos para pessoas com necessidades especiais.

A participação de portadores de deficiência física em eventos competitivos no Brasil e no mundo vem sendo ampliada. Por serem um elemento ímpar no processo de reabilitação, as atividades físicas e esportivas, competitivas ou não devem ser orientadas e estimuladas, visando assim possibilitar ao portador de deficiência física, mesmo durante seu programa de reabilitação alcançar os benefícios que estas atividades podem oferecer, visando uma melhor qualidade de vida.

Concordando com o Dr. Guttmann, Sarrias (1976), ressalta que o esporte pode ser um agente fisioterapêutico atuando eficazmente na reabilitação social e psicologia do portador de deficiência, não devendo ser considerada apenas como uma atividade recreativa.

Souza (1994), enfatiza que o esporte adaptado deve ser considerado como uma alternativa lúdica e mais prazerosa, sendo este parte do processo de reabilitação das pessoas portadoras de deficiências físicas. 
Estas citações são relevantes para atrair a atenção do leitor à importância do presente trabalho monográfico em questão. Foi por este foco de que ao mesmo tempo visionário para um turismo sem distinções, bem como a visão de um político que até inspirou os jogos olímpicos que a autora percorreu falas significativas sobre este delinear, o de locomover com dignidade e sem restrições, reforçando a importância geral da acessibilidade no processo de equiparação de oportunidades no turismo, para pessoas com necessidades especiais de qualquer tipo.

Em suma o desafio foi tentar demonstrar que Brasília é a cidade/capital de todos, especialmente na adoção de medidas que ofereçam acesso a um modelo de turismo sem barreiras. 


\title{
CAPÍTULO I
}

\section{HISTÓRICO}

A história da humanidade revela, desde os tempos mais remotos, a existência de pessoas portadoras de necessidades especiais, com relatos sobre suas dificuldades na vida cotidiana. A Bíblia dá vários exemplos de tais situações, como a deficiência da fala de Moisés (Êxodo, 4:10) ou da visão e física do apóstolo Paulo (Coríntios, cap. 12:7). Na era clássica, esclarece Aurea Ribeiro:

\begin{abstract}
"Homero - aquele a quem Platão denominou na República, o maior de todos os poetas - deixou lavrado em seus versos, a tarefa estratégica legada ao deus Hefesto, que era coxo, ou seja, portador de necessidade especial, o mesmo ocorrendo com Platão, que tinha uma desproporcionalidade física de seus ombros e fortes. A estas pessoas somam-se inúmeras outras, como Ludwig Van Beethoven, ou o Antonio Francisco Lisboa, o Aleijadinho, que assim ficou conhecido devido à deficiência que portava".
\end{abstract}

A trajetória histórica revela que a pessoa portadora de necessidade especial é freqüentemente marginalizada, vivendo num verdadeiro apartheid social, sendo vítima da própria deficiência e da exclusão proporcionada pela sociedade, dita perfeita ou de homens fictícios.

Esta situação é menos evidente nos países que experimentaram os horrores de uma guerra, com a presença de mutilados e, portanto, vítimas sociais, acarretando maior sensibilização e mobilização da sociedade para atender aos seus direitos.

Nos países que não passaram por esta experiência, como o Brasil, o portador de necessidade especial ainda é ignorado e, não raro, discriminado. Pode-se afirmar como certo que o desenvolvimento da sociedade não foi suficiente para diminuir a exclusão e as dificuldades experimentadas, sendo necessário estabelecer por meio de lei, regras que pudessem buscar a igualização entre as pessoas, portadoras de necessidades especiais ou não.

Estas normas, por si só, também não garantiram a efetividade da igualdade, diante da nossa cultura de sociedade perfeita. Assim, os portadores de 
necessidades especiais continuaram marginalizados e excluídos do contexto social. Foi necessário estabelecer mecanismos assecuratórios para garantir a cidadania da pessoa portadora de deficiência, com a previsão de ações judiciais e instituição que assumisse a defesa deste segmento da sociedade.

Neste contexto, surge o Ministério Público como instituição designada para fazer valer os interesses dos portadores de necessidades especiais, visando garantir a sua cidadania, inclusão social e dignidade.

As leis elaboradas passaram a dar respaldo à atuação ministerial, possibilitando o início de uma verdadeira revolução para retirar o portador de necessidades especiais da condição de marginalizado e excluído, elevando-o à condição cidadão com dignidade e respeito.

\subsection{Conceito De Turismo}

Atividade que envolve particularmente aspectos humanos, que correspondem a um mercado de serviços, executadas pelo homem para a satisfação do homem, completamente distinto do mercado de bens de consumo. Busca as diferenças. Envolve um conjunto de aspectos sociais, econômicos e culturais, que fazem com que pessoas se desloquem de seu local de residência a outra vila, por um tempo determinado, retornando a sua origem.

Ao buscar as diferenças - embora sendo um processo temporário - deve ser encarado na monografia como um bem de produção, que gera novos bens e não se esgota na satisfação individual.

\subsection{Classificação de Turismo}

O Turismo, qualquer que seja a sua natureza, tem um grande potencial multiplicador de negócios, capaz não só de propiciar a conexão cultural dos povos e o desenvolvimento social e econômico, gerando benefícios para a localidade e a população receptora nem sempre receptiva, como também para a política empregatícia do setor, em franco desenvolvimento no Brasil. A expansão do Turismo, entretanto, deve respeitar o turista como um cidadão do mundo e com a 
consciência da cidadania; e, paralelamente, respeitar o espaço físico, o meio ambiente e sua conservação no uso e no desenvolvimento sustentável, no que tange aos recursos culturais, naturais e à valorização do patrimônio histórico.

Classificar os tipos de turismo quanto à motivação dos indivíduos não é uma tarefa fácil. Principalmente por que o conceito de turismo não permite que algumas modalidades sejam enquadradas perfeitamente, causando diversas interpretações sobre o assunto. Entretanto, em meio a diversos autores com diferentes classificações, penso que classificar esses segmentos, antes de tudo, como tentar fazer um englobamento de algumas dessas modalidades colocadas por alguns autores. Por exemplo: turismo montanhês. Este deve ser colocado, em minha opinião, dentro de turismo ecológico, já que uma escalada em uma montanha é um modo de aproximação com a natureza. Com este mesmo exemplo, excluo o termo turismo de aventura como uma classificação isolada e a englobo dentro de turismo ecológico, já que escalar uma montanha é uma grande aventura. Então, com este único exemplo dado, vemos a complexidade que é tentar fazer esta classificação.

\subsubsection{Turismo Rural}

Ao iniciar falando sobre turismo rural, é interessante que relembremos que todas as modalidades de turismo são um produto e que esse produto por sua vez, possui suas características especificas e algumas que se enquadram dentro de outras modalidades.

Isto é importante que seja lembrado para que ao estudarmos esta modalidade de turismo ou qualquer outra, tenhamos em mente que este produto é um resultado da oferta de alguma localidade, o que o torna vulnerável a algumas ações causadas por visitantes que por lá passam e podem causar danos ao lugar. Portanto, antes de estudarmos estas modalidades, devemos saber que suas características devem ser analisadas para que não ocorra nenhum incidente por imperícia dos profissionais.

Escrever sobre turismo rural no Brasil, ainda é matéria para poucos, porque a exploração desse segmento turístico, embora já exista há mais de vinte anos, a literatura a respeito ainda é deficiente, a regulamentação oficial da matéria 
também ainda não aconteceu e os profissionais que atuam ou dominam o assunto são apenas alguns.

Iniciando sobre turismo rural. (ZIMMERMANN, 1996, p.23) ${ }^{1}$ define: O turismo rural é um produto que atende a demanda de uma clientela turística, atraída pela produção e consumo de bens e serviços no ambiente rural e produtivo.

Assim sendo, este conceito mostra claramente o que é turismo rural. Em poucas palavras, podemos conceituá-lo como sendo um produto turístico no qual os indivíduos adquirem com o objetivo de vivenciarem experiências ao meio rural, consumindo, usando e participando simultaneamente o dia a dia do campo.

\subsubsection{Turismo Cultural}

Antes de começarmos a falar sobre turismo cultural, surge logo uma pergunta que pode deixar o termo referido como um pleonasmo. Se a cultura (evidentemente) está presente nas destinações visitadas e os turistas estão em contato com ela, podemos dizer que todas as modalidades de turismo são culturais? De certa forma sim. Entretanto, o termo turismo cultural, considero eu, existe para classificar os indivíduos que se deslocam com objetivos principais como conhecer diversas ou especificamente algumas manifestações culturais de uma localidade, sejam materiais que revelam identidade própria e diferencia de outras comunidades culturais.

Segundo (BARRETO, 1995) $)^{2}$ :

O turismo cultural no sentido mais amplo seria aquele que não tem como atrativo principal um recurso natural. As coisas feitas pelo homem constituem a oferta cultural, portanto turismo cultural seria aquele que tem como objetivo conhecer os bens materiais e imateriais produzidos pelo homem.

ZIMMERMANN, Adonis. Turismo rural - um modelo brasileiro. Florianópolis. Ed. Do autor, 1996.

2 BARRETTO, Margarita. Manual de iniciação ao estudo do turismo. 5 ed. Campinas-SP, Papirus. editora, 1995. p. 21 


\subsubsection{Turismo Ecológico}

Falar de turismo ecológico em poucas palavras como estão sendo feitas as outras sínteses é muito complexo. Todas as outras modalidades turísticas (rural, cultural, religiosa, negócios, etc) são bastante amplas. Porém, o turismo ecológico possui uma extensão bem maior em relação aos outros, já que ele possui inúmeros tópicos a serem discutidos. Vejamos:

-conceituação

-Demanda especifica

-Tipos de atrativos

-Impactos ambientais

-Preservação dos recursos naturais

-Envolvimento e benefícios para a comunidade

Não é só esta modalidade que possui estes tópicos. Entretanto é o meio ambiente que mais sofre com a ação dos turistas, o que gera a necessidade de um melhor planejamento e estudo prático e teórico desse tipo de turismo.

Para (BENI, 1998) "o subsistema ecológico abrange, em grande medida, também o subsistema cultural. Tem como principal elemento à contemplação e o contato com a natureza".

Assim sendo, o turismo ecológico baseia-se nessa contemplação dos atrativos naturais existentes em uma localidade: praias, dunas, montanhas, cavernas, etc.

\footnotetext{
${ }^{3}$ BENI, Mário Carlos. Análise estrutural do turismo. 2 ed. São Paulo, editora SENAC, 1998. p. 55
} 
Voltando à questão da importância e complexidade que ele possui. (BENI, 1998) coloca também que:

"Não é que esse subsistema seja mais importante que os demais. Mas pelo fato de o mundo inteiro estar a preocupar-se sempre mais com a ecologia, que, afinal, tem garantido a permanência da espécie humana, de o Brasil estar engatinhando e buscando defender essa preocupação através de grupos de livre formação e de abnegados cientistas, por ser ela, ecologia, o sustentáculo de todas as manifestações de vida planetária e do Sistur, é que temos que mencionar aqui conceitos básicos".

Colocado este motivo principal que é uma crescente "preocupação" com os recursos naturais do planeta percebe-se, olhando pelo lado econômico, a viabilidade que estes recursos podem oferecer, aproveitamento esse que é visto intensamente com o turismo. Também podemos analisar pelo lado psicológico e social, a necessidade que o ser humano sente de fugir das grandes cidades. Ir para lugares onde ele encontre paz ao lado de belas paisagens e de uma intensa contemplação com a natureza, o que o fará encontrar alternativas e até mesmo esquecer da rotina de o seu ambiente de origem: a cidade.

Estes conceitos básicos apontados por Beni não serão considerados aqui como variáveis, já que em uma rápida síntese os mesmos têm grande importância e também em outros contextos pelo fato de estarmos falando de turismo ecológico, e não de ecologia em especifico.

\subsubsection{Turismo Religioso}

O turismo religioso, como o próprio nome diz, é a modalidade de turismo em que os indivíduos se deslocam com um objetivo religioso ou apenas para conhecer certa religião ou movimento religioso.

Para (ANDRADE, 1998) ${ }^{4}$, esse tipo de turismo é: O conjunto de atividades com utilização parcial ou total de equipamentos e a realização de visitas a receptivos

\footnotetext{
${ }^{4}$ ANDRADE, José Vicente. Turismo - fundamentos e dimensões. 8 ed. são Paulo, editora Ática, 1998. p. 77
} 
que expressam sentimentos místicos ou suscitam fé, a esperança e a caridade aos crentes ou pessoas vinculadas a religiões.

Assim sendo, esse tipo de turismo movimenta uma grande quantidade de pessoas o ano inteiro, fazendo com que eventos e rituais religiosos ganhem a cada ano mais e mais força e incentivo para uma melhor estrutura para atender demandas ainda maiores.

No Brasil, em geral, esse tipo de turismo é igualmente praticado por pessoas que possuem algum tipo de devoção a algum santo da igreja católica e viajam para o pagamento de promessas, por motivo de orações ou autoconhecimento. Com isso, nada melhor do que haver um calendário anual com vários eventos (festas, congressos, peças teatrais, entre outras) para atender às expectativas desses fieis que querem viajar com estes objetivos citados acima.

\subsubsection{Turismo De Negócios}

Há uma grande polêmica sobre esta modalidade de turismo. Ao prestar atenção ao conceito de turismo, pode-se ver que turismo de negócios foge à conceituação do mesmo.

No conceito de turismo há de uma forma bem clara que: "não se pode exercer atividade remunerada na localidade". Assim sendo, como pode existir esta modalidade? Este termo existe para não excluir da classificação de turista os indivíduos que viajam a negócios, mas depois usufruem os atrativos, equipamentos e serviços turísticos da localidade.

O conjunto de atividades de viagem, de hospedagem, de alimentação e de lazer praticado por quem viaja a negócios referentes aos diversos setores da atividade comercial ou industrial ou para conhecer mercados, estabelecer contatos, firmar convênios, treinar novas tecnologias, vender ou comprar bens ou serviços, denomina-se turismo de negócios, turismo técnico, viagem de negócios. 
Segundo (ANDRADE, 1998) ${ }^{5}$.

Este conceito resume e explica muito bem por que estes indivíduos são turistas. Entretanto, estes ao viajarem, para entrarem no conceito de turismo, devem realizar os demais tópicos do conceito: permanecer por mais de 24 horas, utilizar meios de transportes, meios de hospedagem, alimentação, em resumo, movimentar a atividade econômica no centro receptor onde ele esteja.

Como historicamente os portadores de necessidades especiais ainda necessitam do apoio e exigências de leis, presentes nessas modalidades de turismo o que importa é assegurar pelo trabalho e experiências profissionais, o direito democrático aos benefícios dessas modalidades, especialmente em Brasília. Como afirma Andrade: "Lazer é um direito que todos tem, o turismo por ser uma das melhores formas de diversão também é um direito dos portadores de necessidades especiais".

${ }^{5}$ ANDRADE, José Vicente. Turismo - fundamentos e dimensões. 8 ed. são Paulo, editora Ática, 1998. p.73, 74 . 


\section{CAPÍTULO II}

\section{TURISMO ADAPTADO}

Uma sociedade mais justa e igualitária pressupõe a inclusão das pessoas portadoras de necessidades especiais, no trabalho e no lazer. No turismo, vem despontando uma especial atenção as crianças portadoras de necessidades especiais.

Além dos Estados Unidos, o país mais preparado em turismo para crianças especiais, Holanda, Inglaterra, França, Alemanha, Suíça e Austrália destacam-se nas facilidades, segundo avaliação de Janaki Nayar, representante da Society for Acessible Travel \& Hospitality (SATH), uma organização não-governamental com sede em Nova York, que trabalha para promover a melhoria das condições de acesso e atendimento para pessoas com necessidades especiais e idosos no turismo mundial. Segundo ela, na América do Sul, os parques nacionais da Patagônia, no Chile, e Machu Pichu, no Peru, são bastante acessíveis. "Nesses lugares, há pessoas capacitadas para receber os portadores de necessidades especiais. Buscamos agora patrocínio para avaliar o Brasil", diz. A SATH publica a revista trimestral Open World (Mundo Aberto em inglês), que oferece sugestões interessantes de roteiros adaptados. "A publicação não mostra a beleza dos lugares, e sim a experiência da pessoa com necessidade especial que orienta como chegar a tal destino", explica Janaki.

A nosso ver o turismo é uma das melhores formas de diversão também para a criança portadora de necessidades especiais, embora ela não possa contar com um serviço especializado no Brasil. "O país ainda está engatinhando nesse setor. O que temos são alguns profissionais com boa vontade, que tentam buscar os melhores locais para o cliente especial. É preciso que tenham quartos adaptados, portas largas, locais com rampas, calçamentos lisos, elevadores e outros serviços", diz Roberto Belleza, consultor na área de viagens e turismo adaptado, que é tetraplégico há sete anos. "As melhores condições de acesso, transporte e atendimento estão nos Estados Unidos e nas principais capitais européias, mas os resorts nordestinos já caminham nessa direção, com construções mais acessíveis", diz o consultor. Se a família pode pagar, Beleza lembra que os cruzeiros marítimos, feitos por modernos 
transatlânticos, são ótima opção para os portadores de necessidades motora e sensorial. "Esses navios oferecem todas as condições. Os pais só precisam elencar as dificuldades do dia-a-dia com a criança para checar as facilidades que podem encontrar na viagem. E não devem pagar mais por esse serviço. Lazer é direito de todos", alerta Beleza.

\subsection{Depoimentos e Entrevistas}

Com os depoimentos e entrevistas que aqui se apresentam, e que foram cuidadosamente selecionados e elaborados para que as pessoas nesta condição pudessem expressar as suas dificuldades e experiências positivas quanto ao acesso ao lazer e sua dignidade resgatada, eventualmente torna-los estudos de casos.

Observemos a riqueza dos seguintes depoimentos registrados na internet, os quais tentaram um alerta das pessoas portadoras de necessidades especiais para os leitores atentos, esperando que suas experiências turísticas resultem em alguma medida para que beneficiam sua qualidade de vida.

\subsubsection{Programa dos sonhos}

Letícia Paula Silveira já foi guia turística, profissão que facilitou o lazer para a filha Pricila, 11 anos, que tem síndrome de Down. "Nós já fomos à Disney seis vezes. É sem dúvida o programa dos sonhos de qualquer criança, mas é um lugar especial pelo cuidado que têm com o portador de necessidade especial. A diversão é garantida". A menina também conhece o Hopi Hari, no interior de São Paulo, e o Beto Carrero World, em Santa Catarina. "As viagens aumentaram muito a autoestima de Pricila. Ela se sente participante do mundo como qualquer outra pessoa. Até quis aprender inglês", conta Letícia. Ana Elizabeth Noll viaja freqüentemente com o filho Denis, portador de paralisia cerebral, desde os 3 anos. "Já fizemos muitos passeios pelo Nordeste brasileiro e também no exterior", conta. Por causa dessas experiências - o garoto está com 18 anos -, ela virou especialista nas falhas e eficiências do turismo para a criança especial. Em 2001, foi chamada para participar da atualização do Manual de Recepção e Acessibilidade da Embratur, 
destinado à indústria turística. Seu conselho aos pais de deficientes: "Não esperem por um turismo adaptado. Viajar com a criança especial provoca as mudanças".

FONTE: http://www.nossaturma.com/ 22/setembro/2003

\subsubsection{Depoimentos De Portadores De Necessidades Especiais}

Bento Gonçalves/Rs - Oi, pessoal! Recebi um convite que me deixou muito feliz. Contar um pouco sobre algumas coisas minhas, sobre a "acessibilidade" nas ruas, enfim, lugares por onde ando. Vou falar um pouco de um lugar que gosto muito de ir aqui em minha cidade... É uma sorveteria, muito simples mas super aconchegante... Gosto muito de falar desse lugar e principalmente das pessoas que ali trabalham porque eles não me vêem como "pessoa portadora de necessidade especial", e sim, me tratam normalmente...

Se eu fosse para lá daqui de minha casa (meio longinho) iria encontrar algumas barreiras, digamos assim... Não seria tão difícil mas existem momentos em que as calçadas são estreitas de mais, lugares um pouco esburacados... Indo do centro não encontro dificuldades, a calçada é muito plana e geralmente os obstáculos são bem menores...

Claro que pra mim as barreiras não são arquitetônicas, uma vez que sou cega e não tenho deficiência física... As pessoas, a receptividade são muito importantes... Claro que o melhor pra gente seria ter um lugar super acessível e adaptado (principalmente pra pessoas portadoras de necessidades física) mas quando as pessoas têm uma visão legal da necessidade, nos tratam normalmente sem nos ridicularizar ou chamar demais a atenção já é uma coisa maravilhosa... Acho que isso a gente consegue muito com a convivência, costumo sempre dizer que conviver é a melhor forma de conhecer e de entender como as coisas são... Tem muita gente que fica com algumas "minhocas", mas com o tempo e a convivência todas essas coisas vão amenizando... Quando as pessoas entenderem que não somos nem heróis nem coitadinhos, mas que somos (apesar de nossas particularidades) pessoas normais, já será um passo enorme... Espero trocar muitas idéias com vocês 
e que juntos possamos conversar sobre as nossas diferenças, dificuldades e conquistas!

\section{Fernanda Magalhães}

Partindo de São Paulo, realizei com minha família uma viagem de férias a três cidades de Minas Gerais. Em uma quinta-feira pela manhã, saímos com destino a Belo Horizonte, onde estão alguns dos meus familiares. Passados dois dias, a Dora, esposa do meu pai, e minha irmã retornaram a São Paulo, permanecendo em viagem eu, meu pai, duas irmãs e minha sobrinha.

Ficamos em Belo Horizonte por três dias na casa de um dos meus tios. Nesse período, encontramos outros parentes, que não víamos há tempos. Entre as saídas que fizemos, fomos a um restaurante que gosto muito, o Xapuri, que é um pouco diferente do tradicional mineiro, ao ar livre e com quiosques de sapé. No outro dia, fomos ao casamento do meu primo, de quem gosto muito.

Na segunda-feira, meu pai foi levar a Dora e minha irmã ao aeroporto e seguimos para Serra do Cipó. Nos hospedamos no Hotel Fazenda Monjolo e, o que me causou admiração, foi a adaptação do espaço: as escadas e rampas tinham corrimãos. Apenas a escada que dava acesso à piscina não tinha.

A Serra do Cipó e suas cidades vizinhas fazem parte da vida de meu pai. Ele conta várias histórias que viveu com seu pai (meu avô) naquele local. Vovô tinha uma jardineira (um tipo de ônibus) que fazia a linha de Peçanha a Belo Horizonte, passando por aquelas estradas precárias e, um dos meus tios era cobrador do ônibus. Papai conta que o vovô, antes de partir com a jardineira, dizia brincando: "Boa viagem e adeus", em função do tempo que a viagem levava: era sempre uma incógnita em razão do estado precário em que se encontrava a estrada, que era de terra naquela época (década de 50).

Hoje, passando pela mesma estrada, a encontramos sem nenhum tipo de cuidado e até desmoronando. Apesar disso, trechos de pontes do século passado estão preservados (cada ponte tem seu ano de construção marcado), porém elas estão desativadas. Uma outra estradinha nos leva à estátua do Juquinha, já falecido. 
O Juquinha era uma pessoa sozinha, não tinha casa, sempre viveu e morou sob uma pedra e sobrevivia do cultivo de orquídeas. Era querido e respeitado por todos que o conheceram e tornou-se uma espécie de guardião daquelas belezas naturais. A estátua, que fica em um descampado de rara beleza, é uma homenagem a ele. Para nos aproximarmos desse monumento, é necessário caminhar por uma pequena trilha. Quando fui, estava chovendo o que atrapalhou um pouco, apesar do acesso ser plano.

Na Serra do Cipó, cuja altitude chega a aproximadamente 900 metros, há muitas trilhas a serem percorridas, mas a maioria é íngreme e acidentada. Por isso, fizemos as possíveis. A trilha que me mais me marcou foi uma que tinham uma subida muito forte e que era usada pelos escravos. Esse caminho leva à parte superior da Cachoeira Véu da Noiva, que tem mais ou menos 60 metros de quedas d'água.

Quando a vimos, achamos que eu não iria conseguir chegar, mas com a persistência da minha irmã mais velha, que tem 25 anos, encaramos o desafio. Minha irmã seguia na frente com minha irmã mais nova, de 10 anos, e com minha sobrinha, que tem 4. Ao mesmo tempo, orientava a mim e a meu pai, que seguíamos atrás. Estávamos com receio, mas mesmo assim, conseguimos vencer os obstáculos e chegarmos ao topo da montanha. Lá do alto pudemos observar a vista deslumbrante e os poços d'água existentes.

Essa trilha, construída pelos escravos, era toda calçada com enormes pedras irregulares e servia como caminho das tropas que faziam o transporte do ouro. 0 grau de dificuldade era, para mim, muito grande em razão da distância, das condições do piso e da inclinação do terreno, mas, com certeza, valeu a pena e eu recomendo.

Fomos também à Cachoeira do Cornélio, atual Cachoeira da Serra Morena a trilha é mais acessível, não há subidas tão fortes. Quando nos aproximamos da cachoeira, aparecem as pedras, nas quais devemos escolher bem onde pisar quando estão molhadas. Do contrário, podemos escorregar. Ao chegar à cachoeira, 
ficamos sentados nas pedras observando e escutando o barulho da água caindo era tudo muito lindo - enquanto as minhas irmãs e minha sobrinha nadavam.

Depois, fomos à Cachoeira Grande, que tem um camping, um bar e um espaço para fazer churrasco. Para ter acesso à cachoeira, precisamos passar por uma mata. Ficamos um pouco sentados à margem do rio sobre as pedras, ouvindo o barulho da cachoeira caindo. Uma delícia! $\mathrm{Na}$ volta, perto do bar, vi que era tudo plano, mas o chão, de terra. Falei ao meu pai que queria tentar andar sozinha para ver o que aconteceria. E adivinha o que aconteceu? Caí de boca no chão, comendo terra! Foi até engraçado!

Em uma das noites, fomos a um restaurante chamado Parador Nacional. É um restaurante muito simpático, com ótimo atendimento e o dono é especialista em vinhos. Ao término do jantar, ele nos convidou para degustar um vinho. A essas alturas, minha sobrinha já tinha adormecido em uma cama improvisada pelo pessoal do restaurante e minha irmã mais nova já estava com muito sono. Eles tomaram vinho, pois não sou muito chegada, e conversamos até tarde.

Após uma semana voltamos para Belo Horizonte, onde nos encontramos com meus tios e com a Dora, que havia chegado de São Paulo no dia anterior. Em seguida fomos para Tiradentes, distante duas horas da capital mineira, onde fizemos alguns passeios. Fomos à Igreja de Santo Antonio, toda revestida de ouro, e em cujo subsolo estão enterradas pessoas. Visitamos também a Igreja dos Escravos, que não podiam freqüentar a mesma Igreja dos brancos e tiveram que construir sua própria.

Tiradentes é uma gostosa cidade da época do Brasil colonial, com muito artesanato, uma culinária excelente e tranqüilidade somente na baixa temporada. Em agosto tem um festival gastronômico que conta com a participação de renomados chefs do Brasil e do exterior e que é uma das maiores atrações turísticas do local.

Visitamos Bichinho, um pequeno lugarejo distante $8 \mathrm{~km}$ de Tiradentes, conhecido pelo seu artesanato e por suas ruas sem calçamento. A cidade é muito 
tranqüila, encontramos lá um restaurante, de um casal paulista, simples e muito gostoso.

Meus dias de férias foram ótimos e inesquecíveis. A Serra do Cipó e Tiradentes são lindas, recomendo e pretendo voltar!

\section{Claudia Bodini*}

Hoje quero falar sobre acessibilidade, mas o que é acessibilidade?

A palavra parece difícil, mas não é. Na verdade, é muito mais fácil do que parece. Acessibilidade vem de acesso, neste caso para facilitar a nossa vida, a dos deficientes físicos. Hoje em dia, o portador de necessidades especiais não é mais aquele indivíduo que fica em casa, em uma cama, fora da realidade do mundo. Estamos trabalhando, estudando nas faculdades, indo aos clubes, nas academias, no comércio, na noite... E se trabalhamos, temos nossa renda e, portanto, também somos um público consumidor.

Mas para que tudo isso aconteça, precisamos de acessibilidade, como rampas nas escolas, nas lojas, cinemas, teatro, precisamos de banheiros adaptados em todos estes lugares e o mais importante: que onde já haja essas adaptações, também exista o respeito por parte dos que não possuem deficiência física.

Vou dar alguns exemplos, alguns bons, outros maus. Outro dia fui para Curitiba com uns amigos para ver uma peça de teatro no teatro do HSBC, um lugar muito bonito, que tem elevador, assim todos têm o acesso ao teatro. Eu achei ótimo, mas em compensação o banheiro que era adaptado para os portadores de necessidades especiais era um depósito de caixas de champanhe. Havia também muitos sacos de lixo, até em cima do vaso.

Agora, um bom exemplo é o teatro Bento Mussurunga, em Castro, no Paraná. Ele acabou de ser reformado e está todo adaptado com rampas, dois lugares na platéia para cadeira de rodas e banheiro adaptado. 
Outro dia, assistindo ao Programa do Jô, ele falou sobre a falta de lugares para obesos em cinemas e teatros. Não tem cadeira grande para essas pessoas, assim muitos deixam de ir a esses lugares por falta de adaptações.

Outra coisa que é um absurdo é que boa parte das Igrejas não possuem rampas e isso também vale para os templos evangélico, centros espíritas, hotéis, motéis, bares, restaurantes. Até em cemitérios rampas são necessárias! Há uma nova lei que fala em adaptações em monumentos históricos.

Acessibilidade: essa é a palavra que facilita a vida dos portadores de necessidades especiais, pessoas obesas, idosos, pessoas que temporariamente estão em cadeira de rodas. Vamos dar mais atenção a este assunto importantíssimo.

\section{Um Passeio a Natal (Rn)}

Oi, gente! Estou retornando da cidade de Natal, no Rio Grande do Norte, onde fui passar uns dias das minhas férias. Prometi que ao retornar iria contar um pouco da viagem, principalmente no que se refere à acessibilidade para PPD (Pessoa Portadora de necessidade especial), uma vez que, como já havia dito em e-mail a equipe Saci, pela primeira vez eu iria me hospedar em um hotel com quarto adaptado para PPD, coisa ainda rara neste nosso País, infelizmente. O dito Turismo Para Todos, aquele que insere, que não discrimina, aquele que democratiza os espaços, os direitos, é ainda um esboço do esboço do que pode vir a ser.

Bem, pretendo narrar aqui a experiência que tive ao utilizar dois serviços oferecidos a PPD's nesta viagem: O atendimento da Companhia Aérea e o do Hotel. Pretendo também falar um pouco da acessibilidade na cidade de Natal/RN.

Quando se fala em viagem, seja ela de que natureza for (a trabalho ou a passeio), planejamento, antecedência e precaução (assim como canja de galinha) não fazem mal a ninguém e são palavras de ordem. Tanto o serviço da Companhia Aérea quanto o do Hotel, nós (eu e minha irmã) solicitamos com antecedência. Para tornar mais clara a narrativa, seguem abaixo os dados: 
Hotel com quarto adaptado onde me hospedei: Ocean Palace Hotel, em Ponta Negra, Via Costeira, km 11, Natal/RN.

Companhia aérea utilizada na ida e vinda de Natal: Varig. Aeroporto de embarque: Aeroporto Internacional do Galeão na Ilha do Governador, Rio de Janeiro/RJ.

Aeroporto de desembarque: Aeroporto Eng. Roberto Freire - BR 101 - Natal/RN.

Minha necessidade especial: Seqüela de Poliomielite, com comprometimento dos dois membros inferiores.

Como me locomovo: Duas muletas canadenses e um aparelho ortopédico na perna esquerda, alternando, para longas distâncias (sempre que possível) o uso com cadeira de rodas.

\section{Como foi?}

Embarque: No aeroporto do Galeão, procuramos informação para fazer o check-in e uma funcionária nos indicou uma sala especial (para PPD, idosos, gestantes, etc) com. poltronas, água gelada, cafezinho, etc, onde logo me foi levada uma cadeira de rodas, que me conduziu até o avião, juntamente com um funcionário da Companhia. Esta cadeira pode levar o PPD até a poltrona do avião, ou somente até a porta do avião, à escolha. Este serviço da Companhia Aérea disponível para PPD foi para mim de grande valia, pois com certeza, eu não conseguiria caminhar a longa distância até o embarque, ficar de pé por muito tempo e subir e descer as escadas pelo caminho. Num determinado trecho do percurso até o avião, um elevador acoplado às escadas, serviu para me transportar na cadeira de rodas até embaixo. Fiquei muito satisfeita com o atendimento, também prestado aos idosos e/ou toda pessoa com dificuldade de locomoção.

Desembarque: A Companhia Aérea providenciou o mesmo serviço. Quando chegamos a Natal, o Comissário do vôo me instruiu que aguardasse, pois um funcionário da Companhia viria me buscar, com cadeira de rodas. Este funcionário recolheu minhas malas e me conduziu até a saída do Aeroporto. Avalio como muito 
positivo o serviço. Quando tudo vai bem, tudo vai bem, rs. Na viagem de retorno ao Rio, tanto o embarque e o desembarque, deram-se da mesma maneira como acima narrado.Dispus de cadeira de rodas e bom atendimento.

Hotel: Éramos eu, minha irmã e minha sobrinha de quatro anos. Chegando ao Hotel observo de imediato, já na entrada, a existência de vaga para carro destinada a PPD, bem localizada, próxima ao hall de entrada. Assim que desci do veículo, o Hotel me ofereceu uma cadeira de rodas (manual), que ficou à minha disposição durante toda a minha estadia e me foi muito útil para locomoção, considerando-se que o Hotel é enorme. Uma vez que quase todo o Hotel dispõe de rampa.(explico o "quase" mais adiante), circulei de cadeira sem grandes dificuldades.

Fomos conduzidas ao quarto.Passo abaixo a expor o que "funciona" (colabora, atende às expectativas,...) e o que "não funciona" (não colabora, é precário, insuficiente, etc...) no quarto adaptado do Hotel:

Funciona:

* A localização do quarto (próxima ao hall da recepção) é excelente, pois facilita a entrada e saída do Hotel, assim como o acesso aos elevadores que conduzem as outras áreas do Hotel (piscina, restaurante...).

* A porta do quarto e do banheiro são largas o suficiente para entrada e saída com a cadeira de rodas.

* O banheiro dispõe de um espaço que pode ser utilizado para deixar a cadeira de rodas, enquanto se toma o banho.

* O boxe do banheiro não oferece obstáculo à entrada da cadeira de rodas. Apenas uma pequena lombada divide o boxe de banho do resto do banheiro.

* Pia rebaixada.

* Espelho da pia regulável. 
* Dispositivos para ligar e desligar o ar condicionado na cabeceira da cama.

O que não funciona:

- Todo o banheiro (e parte da entrada do quarto) é coberto com piso de mármore altamente escorregadio.Precisei ter cuidados redobrados para não cair e me ferir seriamente.

* O boxe de banho não dispõe de barras de apoio e piso antiderrapante.

* O boxe de banho não dispõe de assento.

* O vaso sanitário não dispunha de barras de apoio ao seu redor. A pedido as barras, afixadas no piso por pregos de encaixe, foram colocadas, mas foi preciso pedir.

* O restante do quarto é coberto com piso de lajotas muito escorregadio, o que tornava perigoso a locomoção com muletas.

* O espaço para circulação com a cadeira de rodas era muito estreito. Apesar do quarto ser amplo, com três camas largas, mesa para refeição, bancada para televisão, penteadeira, etc, a sua arrumação e disposição de móveis não consideraram a circulação de uma cadeira de rodas.

Todos estes fatores fizeram com que eu precisasse constantemente da ajuda da minha irmã para atividades que eu normalmente executo sozinha, sem precisar de auxílio. Ironicamente, neste quarto adaptado eu fiquei bem menos independente do que realmente sou na vida diária.

Logo acima falei que "quase" todo o Hotel dispõe de rampa e é verdade. Quase todo o Hotel é acessível. Há rampas para a piscina e acesso fácil aos restaurantes e hall do Hotel. Os elevadores recebem bem a cadeira de rodas e entra-se sem dificuldade. Onde não há rampas então? No segundo andar do Hotel (inexplicavelmente). Se você desejar ir à loja de artesanato, sala de massagem, salão de belezas, academia de ginástica e sala de recreação, peça ajuda. Não há 
acesso senão pela escada. É possível, pela rampa que sai da piscina (sinuosa, muito íngreme e sem corrimão) chegar próximo aos lugares que falei acima, mas ainda assim será preciso enfrentar alguns degraus de escada (sem corrimão) para adentrar os recintos. Inviável. O mesmo se repete para chegar à praia de Ponta Negra. O Hotel, que fica às margens desta linda praia, só pode ser acessado por escadas (muitas escadas!). Acreditando que o estabelecimento que oferece espaços adaptados para PPD’s quer realmente democratizar acessos e uso, e que nós cidadãos portadores de necessidades especiais devemos cobrar e colaborar com sugestões e críticas, relatei todas estas observações num formulário (fornecido pelo Hotel) sugerindo as cabíveis mudanças, que espero sirvam para o aprimoramento do serviço, mesmo porque percebi no Hotel muita vontade em bem servir e melhorar. Apesar de todos os empecilhos, o Ocean Palace oferece um atendimento de excelente qualidade e funcionários extremamente solícitos. Recomendo a todos. Quem sabe neste ínterim, eles já tenham feito as adequações necessárias! Pelo que me consta (espero estar enganada) o Ocean Palace é o único Hotel em Natal/RN que oferece quarto adaptado para PPD. Ponto para eles.

\section{Natal/RN}

Natal é uma cidade linda e hospitaleira, mas como a grande maioria das cidades brasileiras, é precária em acessibilidade para PPD, deixando muitíssimo a desejar neste aspecto. Circular pelas ruas da cidade de cadeira de rodas ou mesmo de muletas é um exercício de titã. Não há rampas nas calçadas, transporte adaptado, estacionamento para veículo de PPD, etc. As calçadas são altíssimas e em muitos trechos o terreno é bastante acidentado. Barreiras arquitetônicas, barreiras sociais.

No Natal Shopping (o maior Shopping atualmente na cidade) pude dispor de uma cadeira de rodas para circular enquanto lá estive, bastando para isso deixar minha identidade com o responsável no segundo piso (acessível por elevador). O Shopping oferece transporte (ônibus) do Hotel ao Shopping e de volta ao Hotel. O ônibus tem degrau altíssimo e não dispõe de espaço para cadeira de rodas. Entrei e saí carregada. 
Apesar de tudo, quero salientar que adorei Natal/RN, seu povo, sua gente, sua alegria e simpatia. A cidade é belíssima em suas belezas naturais, com suas praias limpas de água verde, muito coqueiro e brisa, um convite ao lazer e ao descanso.

Viajar é muito bom. Viajemos, apesar das barreiras viajemos, devemos viajar, apesar dos obstáculos devemos estar, deixar que nos vejam, nos conheçam, saibam de nós, nos toquem, nos percebam em nossa dimensão humana (que nos irmana a todos sem distinção), porque é no percurso, no trânsito que refinamos o olhar (o nosso e do outro), é no embate que lapidamos as asperezas, nossas e alheias, e vamos nos reconhecendo como detentores dos mesmos direitos e deveres, e das mesmas lacunas, parceiros numa luta que nos transcende; viajemos porque é neste encontro que visitamos e somos visitados, possibilitamos o reconhecimento e respeito às diferenças. Aqui ou lá, eis uma parte integrante deste nosso País, de tantas caras e belezas, que tanto precisa progredir, democratizar direitos, abraçar as diferenças, diminuir as desigualdades, construir enfim um Turismo Para Todos. Para Todos.Por hora, para todos este forte Abraço!

FONTE: www.saci.org.br/index.php?modulo=\&parâmetro=3040 26/setembro/2003.

\subsubsection{Entrevista Com Portadores De Necessidades Especias Moradores Em Brasília}

Por outro prisma, podemos verificar a percepção dos moradores de Brasília, cujo critério de seleção foram distintos domiciliares, classes sócio-econômicas diversas e faixas etárias variadas. O denominador comum é ser portador de necessidades especiais, os quais foram minuciosamente selecionados dos inúmeros questionários respondidos, para mostrar sua autenticidade mediante amostragem das três deficiências básicas que residem em Brasília. A intenção secundaria foi verificar o grau de acessibilidade dos moradores de Brasília, já que esta monografia defende que Brasília, é uma das cidades turísticas que mais atendem e se preocupam com os portadores de necessidades especiais. Verificamos portanto suas reivindicações e como ainda tem muito a se fazer por eles. 
1 - FRANCISCO DAS CHAGAS RODRIGUES DASILVA

NASCIDO EM 01/01/1971 NO PIAUI

RESIDE NO GAMA A Q 01 CJ. Q CASA 14 - SETOR SUL

DEFICIÊNCIA AUDITIVA

1) Em quais locais você gostaria que houvesse uma estrutura de atendimento, levando-se em conta a sua necessidade especial?

(x) estabelecimentos públicos

(X) farmácias e drogarias

(X) hospitais públicos ou particulares

(X) restaurantes

(X) lanchonetes

(X) supermercados

(X) hotéis

(X) shopping

(X) galerias

(X) lojas

(X) clubes

(X) teatros

(X) bancos

(X) pontos turísticos

2) Em quais meios de transporte público o atendimento não é satisfatório?

( X) ônibus ( ) trem ( X )metrô ( )lotação ( ) outros 
Obs: No metrô ele sugere que deve haver algum sinal luminoso indicando perigo, quando for o caso, porque eles falam pelo alto falante e o deficiente auditivo não percebe. Em caso de algum imprevisto durante o percurso de ônibus ou metrô, lembrar sempre que pode haver alguma pessoa com deficiência auditiva.

3) Você tem encontrado bom atendimento nos restaurantes e lanchonetes?

( )sim (X)não

4) Julga importante um serviço permanente de atendimento de emergência $24 \mathrm{~h}$ para portadores de necessidades especiais que morem ou estejam temporariamente sozinhos em casa, em caso de acidente ou doença?

(X)sim ( )não

5) Com quais estabelecimentos gostaria de ter convênios?

( ) farmácias e drogarias

( ) restaurantes

( )lanchonetes

( )supermercados

( )lojas de CD

( )lojas de materiais especializados

( )hotéis

( )pousadas 
( )companhias de turismo

(X)hospitais

6) Você tem dificuldade de acesso às informações contidas nos diversos shoppings?

(X)sim ( )não

7) Assinale as companhias aéreas pelas quais você tem viajado.

( )Varig (X)Vasp ( )TAM ( )Transbrasil ( ) TAP ( ) Air Portugal

( ) Air France ( )outros

8) Essas companhias dispõem de manuais de procedimentos a serem tomados por portadores de necessidades especiais?

( $) \operatorname{sim}(X)$ não

Obs: Se estiver dirigindo e houver uma batida, deve haver sempre uma pessoa para traduzir em sinais. O bombeiro, por exemplo, deve ser treinado ou saber como solicitar alguma pessoa para esse atendimento. Portanto treinamento a pessoas para atendimento a deficientes auditivos é muito importante. Quando tenho que ir ao médico, banco, órgão da justiça, restaurantes ou outro tenho que providenciar e levar interprete. Olha o absurdo que acontece, fui a um restaurante o qual tinha musica e cobrava couvert artístico, tive que pagar mesmo não tendo escutado nada. Em recepções de hotéis nunca tem ninguém para interpretar o surdo. Quando viajei de avião não percebi o que estava sendo explicado, porque eles falavam no alto falante e eu não ouvia. Em ônibus de turismo, tem sempre um guia dando explicações no alto falante e nunca alguém traduzindo para o deficiente auditivo. Portanto, é necessário pessoas serem treinadas para lidar com esses deficientes. 
2 -ELAYNE CRISTINA FREITAS ALBUQUERQUE 3 - MARIA LUCIANA FREITAS DE ALBUQUERQUE NASCIDO EM BRASÍLIA EM 08/02/83

RESIDE NO GUARA I QI 11 CJ. M CASA 32

DEFICIENCIA FISICA - CADEIRANTE

1)Em quais locais você gostaria que houvesse uma estrutura de atendimento, levando-se em conta a sua necessidade especial?

(X) estabelecimentos públicos

(X) farmácias e drogarias

(X) hospitais públicos ou particulares

(X) restaurantes

(X) lanchonetes

(X) supermercados

$(X)$ hotéis

(X) shopping

$(\mathrm{X})$ galerias

(X) lojas

(X) clubes

$(\mathrm{X})$ teatros

(X) bancos

(X) pontos turisticos

2)Em quais meios de transporte público o atendimento não é satisfatório?

(X) ônibus ( ) trem (X)metrô ( )lotação ( ) outros

Obs: O seu maior desejo é que os ônibus sejam adaptados para cadeirantes, para se locomover só, sem depender do pai. Os ônibus de turismo também devem ser adaptados para cadeirantes.

3) Você tem encontrado bom atendimento nos restaurantes e lanchonetes? 
(x)sim ( )não

4) Julga importante um serviço permanente de atendimento de emergência $24 \mathrm{~h}$ para portadores de necessidades especiais que morem ou estejam temporariamente sozinhos em casa, em caso de acidente ou doença?

(X)sim ( )não

5) Com quais estabelecimentos gostaria de ter convênios?

( ) farmácias e drogarias

( ) restaurantes

( ) lanchonetes

( ) supermercado

( ) lojas de CD

( ) lojas de materiais especializados

( ) hotéis

( ) pousadas

( ) companhias de turismo

( ) hospitais

6) Você tem dificuldade de acesso às informações contidas nos diversos shoppings?

( ) $\operatorname{sim}(x)$ não 
7) Assinale as companhias aéreas pelas quais você tem viajado.

( )Varig (X)Vasp ( )TAM (x)Transbrasil ( ) TAP ( ) Air Portugal

( ) Air France ( )outros

8) Essas companhias dispõem de manuais de procedimentos a serem tomados por portadores de necessidades especiais?

( ) $\operatorname{sim}(X)$ não

- Solicita que as empresas aéreas tenham cadeiras de rodas adaptadas dentro do avião.

- Quando tem que ir a alguma loja, sempre tem que ter alguém acompanhando, devido balcões altos, locais não adaptados.

- Ela disse que todos os locais de divertimento que vai tem acesso.

-Sua reclamação é em relação às salas de cinemas, que o local designado para cadeiras de rodas é na última fileira.

\section{4 - LUZIA DE MARILAC CATANHEDE}

RESIDENTE A SUDOESTE TELEFONE 344-3913

DEFICIEENCIA VISUAL

1) Em quais locais você gostaria que houvesse uma estrutura de atendimento, levando-se em conta a sua necessidade especial?

( ) estabelecimentos públicos

( ) farmácias e drogarias

( ) hospitais públicos ou particulares

( ) restaurantes

( ) lanchonetes 
( ) supermercados

( ) hotéis

(x) shopping - pessoas preparadas para lidar com deficientes visuais

( ) galerias

( ) lojas

(X) clubes

(X) parques- solicita maior segurança

2)Em quais meios de transporte público o atendimento não é satisfatório?

( ) ônibus ( ) trem ( )metrô ( )lotação ( ) outros

Obs: Nos ônibus uma maior atenção dos motorista e cobradores.

Pessoas mais preparadas.

3) Você tem encontrado bom atendimento nos restaurantes e lanchonetes?

( ) $\operatorname{sim}($ )não

4) Julga importante um serviço permanente de atendimento de emergência $24 \mathrm{~h}$ para portadores de necessidades especiais que morem ou estejam temporariamente sozinhos em casa, em caso de acidente ou doença?

( ) $\operatorname{sim}$ ( )não

5) Com quais estabelecimentos gostaria de ter convênios?

( ) farmácias e drogarias

( ) restaurantes 
( ) lanchonetes

( ) supermercados

( ) lojas de CD

( ) lojas de materiais especializados

( ) hotéis

( ) pousadas

( ) companhias de turismo

( ) outros

6) Você tem dificuldade de acesso às informações contidas nos diversos shoppings?

( $) \operatorname{sim}(X)$ não

7) Assinale as companhias aéreas pelas quais você tem viajado.

(X)Varig (X)Vasp (X)TAM ( )Transbrasil ( ) TAP ( ) Air Portugal GOL (X)

( ) Air France ( )outros

8) Essas companhias dispõem de manuais de procedimentos a serem tomados por portadores de necessidades especiais?

( )sim) (X)não

Sugestões 


\section{5 - LUIZ LOPES}

\section{ASA NORTE 349-5632}

1) Em quais locais você gostaria que houvesse uma estrutura de atendimento, levando-se em conta a sua necessidade especial

(X) estabelecimentos públicos

( ) farmácias e drogarias

(X) hospitais públicos ou particulares

(X) restaurantes

(X) lanchonetes

(X) supermercados Sugere que as vagas para deficientes sejam fiscalizadas, porque nunca encontra uma vaga.

(X) hotéis

(X) shopping

( ) galerias

( ) lojas

(X) parques

(X) clubes

2) Em quais meios de transporte público o atendimento não é satisfatório?

( x ) ônibus ( ) trem ( )metrô ( )lotação ( ) outros

Sugere que os profissionais sejam mais qualificados e treinados para lidar com os deficientes visuais.

Já caiu quando descia do ônibus, e machucou bastante, o motorista não esperou ele descer direito do ônibus e arrancou com o veiculo.

3) Você tem encontrado bom atendimento nos restaurantes e lanchonetes?

( ) $\operatorname{sim}(X)$ não 
4) Julga importante um serviço permanente de atendimento de emergência 24 para portadores de necessidades especiais que morem ou estejam temporariamente sozinhos em casa, em caso de acidente ou doença?

(x)sim ( )não

5) Com quais estabelecimentos gostaria de ter convênios?

( ) farmácias e drogarias

( ) restaurantes

( ) lanchonetes

( ) supermercados

( ) lojas de CD

( ) lojas de materiais especializados

( ) hotéis

( ) pousadas

( ) companhias de turismo

( ) outros

6) Você tem dificuldade de acesso às informações contidas nos diversos shoppings?

( ) $\operatorname{sim}(x)$ não

7) Assinale as companhias aéreas pelas quais você tem viajado. 
(x)Varig ( )Vasp (x)TAM (x)Transbrasil ( ) TAP ( ) Air Portugal

( ) Air France ( )outros

8) Essas companhias dispõem de manuais de procedimentos a serem tomados por portadores de necessidades especiais?

( ) sim) (x)não

A intensidade e o volume de reivindicações já são perceptíveis apenas por uma primeira leitura desses depoimentos. No contexto desta monografia, funcionam como advertência ainda insuficiente cumprimento da legislação pelas autoridades governamentais, evidenciando a importância da proposta da autora: turismo sem barreiras. 


\section{CAPÍTULO III}

\section{TURISMO E ACESSIBILIDADE}

O constante crescimento do turismo vem tornando este setor um dos mais dinâmicos na área de comércio e serviços. Para trabalhar na área é necessário vasto conhecimento técnico, além de habilidades individuais para atender à diversidade de serviços.

\subsection{Analisando o profissional do TURISMO}

1 - A geração de empregos será, em todos os setores, a grande preocupação e desafio do novo milênio. Com o avanço da tecnologia o número de postos de trabalho diminui, logo, somente a indústria, não será suficiente para empregar toda a mão-de-obra existente. O setor de serviços será aquele responsável por absorver a maior parte da população economicamente ativa no mundo. Por ser o turismo um setor eminentemente de serviços, Ihe caberá uma fatia representativa desse universo. Em todo o mundo o segmento de turismo vem apresentando um crescimento significativo, sendo a atividade que mais emprega, pois para cada dez postos de trabalho gerados no cômputo geral, pelo menos um deles é voltado para o turismo. Portanto, a economia mundial está aos poucos centrando-se nas atividades desse importante segmento.

Muito ainda deve ser feito visando o aprimoramento e a capacitação da mãode-obra turística, porém duas são mais relevantes. A primeira refere-se à formação de empreendedores que já atuam no ramo e que ainda não dão a devida importância às etapas precedentes à implantação de um projeto turístico, além da capacitação dos conhecimentos da mão-de-obra laboral. A segunda, passa por questões de modernização e acompanhamento da nova era decorrente da globalização.

Segundo TRIGO (1998)

${ }^{6}$ TRIGO . Competência e eficiência profissional. 1998, p. 205 
"Em um mundo caracterizado por uma nova ordem econômica internacional, novas tecnologias e forte competitividade em mercados atingidos pelo desemprego, o profissional tem que se impor pela competência e eficiência. É necessário também que esse profissional tenha uma postura ética e não subestime a capacidade e as aptidões dos outros profissionais, graduados em diversos cursos superiores e que disputam empregos no turismo. O setor é extremamente mutável, dinâmico e, no caso do Brasil, ainda bastante instável".

2 - Segundo Caio Luis de Carvalho, enquanto Ministro do Esporte e Turismo, dois itens são essenciais para o crescimento do turismo no País - infra-estrutura básica e capacitação. Somente no Nordeste do Brasil através do Programa de Desenvolvimento do Turismo. - PRODETUR/NE, nos últimos 06 anos foram construídos através 08 novos aeroportos, 22 mil metros de patrimônio histórico foram restaurados, 17 projetos de saneamento em áreas turísticas foram executados e 280 quilômetros de estradas foram construídos, só de acesso turístico.

Entretanto, para que o turismo possa ser o setor responsável pela geração de emprego e renda no mundo globalizado, é fundamental que a mão-de-obra a ser empregada esteja preparada para tal, uma vez que para que o turismo tenha êxito, somente uma bela paisagem não é suficiente: é necessário que sejam ofertados serviços adequados, com profissionalismo e hospitalidade, cuja responsabilidade não está somente a cargo daqueles que lidam diretamente com o turista, quer seja taxista ou recepcionista do hotel, conta também com a participação da comunidade anfitriã, que deverá está comprometida em receber bem o cliente.

\subsection{Gastronomia}

Independentemente da condição física dos turistas, a gastronomia é um item indispensável para um turismo de qualidade. Os aspectos tradicionais da cultura, como as festas, as danças e a gastronomia, também fazem parte do consumo turístico. Nesse contexto, as receitas culinárias constituem um bem cultural tão valioso quanto um monumento, já que possibilitam entender a história de um lugar por meio de sua gastronomia. 
Com a cozinha atual sendo afetada pela globalização, que padroniza tudo, esse interesse do turismo pela gastronomia pode ajudar a resgatar antigas tradições que estão prestes a desaparecer.

O presidente da Abresi destaca a multiplicidade como uma das principais características da cozinha brasileira, o que para ele é um grande atrativo para o turismo interno. "De norte a sul há cozinhas regionais ricas e diferenciadas. Vale um tour pelo Brasil só para conhecê-las", afirma.

Tanta fartura e diversidade também estão fazendo a culinária brasileira ser exportada para outros países, com base no tripé feijoada, pão de queijo e caipirinha. A Forno de Minas (General Mills), está incrementando as vendas para os Estados Unidos, onde a empresa começa a operar por meio da Triunfo Importation Exportation Food Corporation, maior distribuidora de alimentos portugueses em território norte americano.

A caipirinha é outro destaque mundial. Com mais de 5 mil marcas de cachaça e cerca de 30 mil produtores, o Brasil encerrou o ano passado com uma produção de 1,3 bilhão de litros. Deste volume, 14,8 milhões de litros seguiram para 0 mercado externo - a maior parte para a Europa, especialmente Alemanha, que consome mais de 30 \% do total exportado. Os dados são do Programa Brasileiro de Desenvolvimento da Cachaça (PBDAC), que reúne os produtores da bebida. Segundo Maria das Vitórias Cavalcanti, presidente do conselho deliberativo do PBDAC, as projeções para o setor são de crescimento de 30 \% das exportações em 2003 e atingir 50 milhões de litros até o final da década.

A churrascaria gaúcha Fogo de Chão abriu este ano sua quinta filial norteamericana, em Los Angeles. O movimento de estrangeiros em churrascarias é tanto que a Boizão Grill, em São Paulo, instalada na marginal Tietê, nas proximidades do Anhembi - que concentra um grande movimento de feiras internacionais -, fez um folheto com os nomes dos cortes de carne em inglês.

O Brasil, aliás, exporta até pizza. A paulistana A Tal da Pizza tem uma filial em Miami, onde faz muito sucesso há quatro anos, e outra em Weston, próxima a Fort 
Laudardale, criada há menos de um ano. Com um consumo estimado de 1,4 milhão de pizzas por dia, segundo dados da Abresi, São Paulo serve muitos turistas interessados em conhecer os criativos recheios da pizza "brasileira".

\subsubsection{Comida de Branco}

Nos tempos do descobrimento, os índios provaram a comida de branco. Não gostaram. Segundo Pero Vaz de Caminha, dois tupis foram levados à nau capitânia, e recebidos pelo próprio Pedro Álvares Cabral. Provaram peixe cozido, confeito, fartéis (um doce delicado, envolvido em capa de massa de trigo), mel e figos secos. Não comeram quase nada. Quando provavam algo, logo cuspiam enojados. Nem o vinho apreciaram. Fonte: Crônicas dos Viajantes, Séc. XVI apud Unidades III e IV do volume Brasil: Unidade e Diversidade da coleção Geografia - Espaço, Cultura e Cidadania.

Em compensação, os portugueses gostaram dos camarões, que já conheciam, mas não tão grandes. Os hábitos mudaram muito, com a integração da região pelas estradas, porém se conservam nas comunidades mais isoladas. A mudança de costumes eliminou também a tanajura ou içá, iguaria elogiada no tempo dos nossos avós, hoje desprezada. Monteiro Lobato brincava: "O içá torrado é o que no Olimpo grego tinha o nome de ambrosia".

Pratos tradicionais podem ser apreciados nas casas de famílias antigas, e nos bons restaurantes caiçaras. Peixe com banana, no famoso azul-marinho; camarões a paulistinha, caldeiradas e afogados fazem a alegria de todos. Doces de banana, sorvetes sofisticados, não falta variedade na rica culinária do litoral, nem sabores exóticos dos restaurantes internacionais que pontilham as praias e centros.

Realização do $13^{\circ}$ CIHAT - Congresso Internacional de Gastronomia, Hospitalidade e Turismo mostrou a sociedade brasileira aos participantes e palestrantes que vieram de diversas partes do Brasil, da América Latina e Europa, aos estudantes e aos empresários do setor, que a grande saída para a economia é o turismo e as atividades que nele se engajam como um todo. 
No Brasil, o turismo está em franca expansão, com a construção de hotéis, parques temáticos e outros empreendimentos turísticos, que serão responsáveis pela criação de empregos, além da necessidade de aperfeiçoamento de mão-deobra, qualificação e requalificação de profissionais do setor. Isso desencadeia um processo contínuo que começa na oferta de empregos e se oriente nas escolas, responsáveis pela formação de novos profissionais.

Este OIHAI deixou clara a expectativa que todos tem com relação ao turismo, como atividade geradora de emprego e renda para os trabalhadores e o anseio dos jovens que participaram do evento com relação a seu futuro.

É aí que entra o trabalho de entidades representativas do naipe da ABRESI Associação Brasileira de Gastronomia, Hospitalidade e Turismo, da CNTur Confederação Nacional do Turismo e entidades de ensino voltado para formação de profissionais de turismo e gastronomia como a Escola João Dôria Junior do Sindicato de Hotéis, Restaurantes, Bares e Similares de São Paulo.

Essas entidades formam profissionais de gabarito, habilitados para atender adequadamente a demanda do setor, que será crescente neste milênio. Todas estas questões deságuam na necessidade do Ministério do Trabalho e Emprego, sensibilizar-se e conceder a CNTur seu registro sindical, pelas ações por ela desencadeadas e pelo reconhecimento que a entidade possui da entidade representativa dos empregados,a CONTRATUH que reconhece a CNTur como, representante do contraponto que tem que existir entre empregadores e empregados.

\subsection{A melhor Idade e portadores de necessidades especiais}

Com o processo de envelhecimento da população mundial, o público formado por pessoas com mais de cinqüenta anos, denominado pelos turismólogos de melhor idade, passou a ser um mercado bastante atrativo para o turismo. Sabe-se que a população brasileira é uma das mais velhas da América Latina dados do 
Instituto Brasileiro de Geografia e Estatística ( IBGE, 2001) ${ }^{7}$, e a expectativa de vida do País cresce a cada ano, bem com o número de filhos por família diminui. Estimase que até 2025, o Brasil esteja entre as seis maiores populações de idosos do mundo.

A Melhor Idade representa, atualmente, de 16\% a 35\% dos clientes ativos das agências de turismo, representando na visão do turismo, como um segmento bastante promissor, uma vez que se destina à clientela detentora de tempo livre, que pode viajar até mesmo na baixa estação. Desse público, 72\% usa avião como meio de transporte, $87 \%$ utilizam hotéis, e $68 \%$ deles possuem cartões de crédito. Sabese também, que o Brasil possui 13 milhões de portadores de necessidades especiais, pessoas que enfrentam inúmeras dificuldades para viajar e aproveitar seus momentos de lazer. A primeira dificuldade que ocorre logo quando do deslocamento, é que os transportes não são adaptados para portadores de necessidades especiais, sendo inúmeras as barreiras encontradas ao longo do roteiro a ser percorrido (escadas, rampas sem corrimão, portas estreitas, calçadas ocupadas por automóveis, barreiras arquitetônicas, dentre outros).

Diante dessas evidências, entidades públicas, aliadas ao setor turístico e aos associados de clubes da Melhor Idade, devem avaliar e tomar providências no sentido de que seja iniciado um processo de reformulação na infra-estrutura turística, compreendendo os equipamentos turísticos e suas instalações, a capacitação da mão-de-obra laboral e de gestão, voltadas para atendimento diferenciado ao idoso e ao portador de necessidade especial, além da disponibilização de pacotes que ofereçam atividades compatíveis com o perfil desses segmentos.

\subsubsection{Acessibilidade}

\section{Lei $n^{\circ} 10.098$, de 19 de dezembro de 2000}

Estabelece normas gerais e critérios básicos para a promoção da acessibilidade das pessoas portadoras de deficiência ou com mobilidade reduzida, e dá outras providências.

\footnotetext{
${ }^{7}$ IBGE - Instituto Brasileiro de Geografia e Estatística. A expectativa de vida no país. 2001.
} 
É direito do portador de necessidades especiais à acessibilidade, as leis existem mas não estão instituídas.

Faz-se necessário iniciar medidas que removam os obstáculos à participação no ambiente físico. Tais medidas devem desenvolver padrões e diretrizes e considerar a promulgação de leis para garantir a acessibilidade aos portadores de necessidades especiais, tais como moradia, edifícios, serviços de transportes públicos e outros meios de transporte, ruas e outros ambientes externos, garantir que os arquitetos, engenheiros civis e outros profissionais envolvidos no projeto de construção do ambiente físico tenham acesso a informações adequadas sobre política de deficiência e providências necessárias à acessibilidade.

Os requisitos da acessibilidade devem ser incluídos no projeto e construção do ambiente físico desde o início do processo de projeto.

As organizações de pessoas portadores de necessidades especiais embora não sejam turistas em suas entidades de classe devem ser consultadas quando estiverem sendo desenvolvidos padrões e normas de acessibilidades. Elas devem também ser envolvidas no nível local desde a etapa do planejamento inicial dos projetos de construção pública, garantindo, assim, a máxima acessibilidade.

\subsubsection{Eliminando Barreiras}

Buracos, desníveis (às vezes, bastante grandes), raízes de árvores, carros estacionados, mesas e cadeiras, tambores ou sacos de lixo, camelôs, tampas de bueiros quebradas, hidrantes, orelhões e caixas de correio colocados irregularmente, são obstáculos que podem ser encontrados facilmente, ao se caminhar pelas calçadas da maioria das cidades. Se isso é desgastante para qualquer pessoa, vejamos a situação com o olhar de pessoas portadoras de alguma deficiência, sobretudo física ou visual.

"É preciso tornar as cidades mais humanas, eliminando os riscos de acidentes e integrando melhores pessoas portadoras de necessidades especiais, excessivamente altas ou baixas, idosos, gestantes e crianças". diz Adriana Romeiro 
de Almeida Prado, arquiteta urbanista, técnica da Fundação Prefeito Faria Lima CEPAM, onde coordena trabalhos relativos à eliminação de barreiras e à acessibilidade. Diz ainda: "Tornar o espaço acessível, é eliminar obstáculos físicos, naturais ou de comunicação que existam nas cidades, nos equipamentos e mobiliários urbanos, nos edifícios, nas várias modalidades de transporte público que impeçam ou dificultem a livre circulação dessas pessoas" ${ }^{\prime 8}$.

A evolução da luta pela acessibilidade, que é em nível mundial já existe há três décadas mostrou a importância de se projetar para todos, pois a solução que atende a um tipo de necessidade pode dificultar outro indivíduo.

Um ambiente acessível é melhor e mais seguro para todos, mas tem, geralmente, seus custos questionados. Entretanto, os técnicos afirmam que os gastos com a acessibilidade são inferiores ao que se imagina, sobretudo se as adaptações são incorporadas desde o projeto. "Quando o projeto já nasce adaptado", diz Adriana, "o custo que se acrescenta normalmente não chega a 2\%".

Adriana diz ainda:

"É bom lembrar que possibilitando o acesso a essas pessoas, estamos tornando a vida delas mais independente e segura, liberando assim, para o mercado de trabalho, além do portador de deficiência, mais uma pessoa que ficava presa à atividade de assisti-la. Por esse motivo, os americanos dizem que, para cada dólar investido, há um retorno social de sete dólares".

\section{Como realizar as adaptações necessárias para proporcionar comodidade ao portador de deficiência física?}

Seguindo a Norma NBR 9050 da Associação Brasileira de Normas Técnicas ${ }^{9}$, órgão responsável pela padronização dos objetos e edifícios no Brasil, divulgamos aqui medidas que poderão auxiliá-lo na realização de adaptações em sua casa:

\footnotetext{
${ }^{8}$ Adriana Romeiro de Almeida Prado, arquiteta urbanista, técnica da Fundação Prefeito Faria Lima - CEPAM.

${ }^{9}$ http://www.abnt.org.br/
} 
As portas deverão ter um vão de $80 \mathrm{~cm}$ e uma maçaneta do tipo alavanca a $90 \mathrm{~cm}$ de altura. Os corredores devem ter no mínimo 1,20m de largura, mesmo tamanho aconselhado para as rampas, que devem ter a declividade máxima de 12,5 graus e inclinação de 8 graus. A guia da calçada deve estar a $15 \mathrm{~cm}$ de altura e conter uma saliência de $1,5 \mathrm{~cm}$ no ponto mais baixo da rampa para portadores de deficiência visual. Quanto ao botão do elevador, deve estar a 1,15 cm de altura.

O boxe do banheiro pode ser dotado de um banco com $46 \mathrm{~cm}$ de altura e 46 $\mathrm{cm}$ de largura e de uma ducha manual direcionável. É necessário que exista também uma barra de apoio horizontal a $90 \mathrm{~cm}$ de altura e uma saboneteira a, no máximo, $1 \mathrm{~m}$ do chão. O lavatório deve estar a $80 \mathrm{~cm}$ de altura e ter uma torneira de alavanca a $1 \mathrm{~m}$, mesma altura recomendada para o toalheiro. Quanto aos mictórios, eles devem estar a $46 \mathrm{~cm}$ do piso com duas barras de apoio fixas na vertical a $70 \mathrm{~cm}$ do piso. As barras devem ter um vão de $80 \mathrm{~cm}$ entre si e a mesma medida de comprimento.

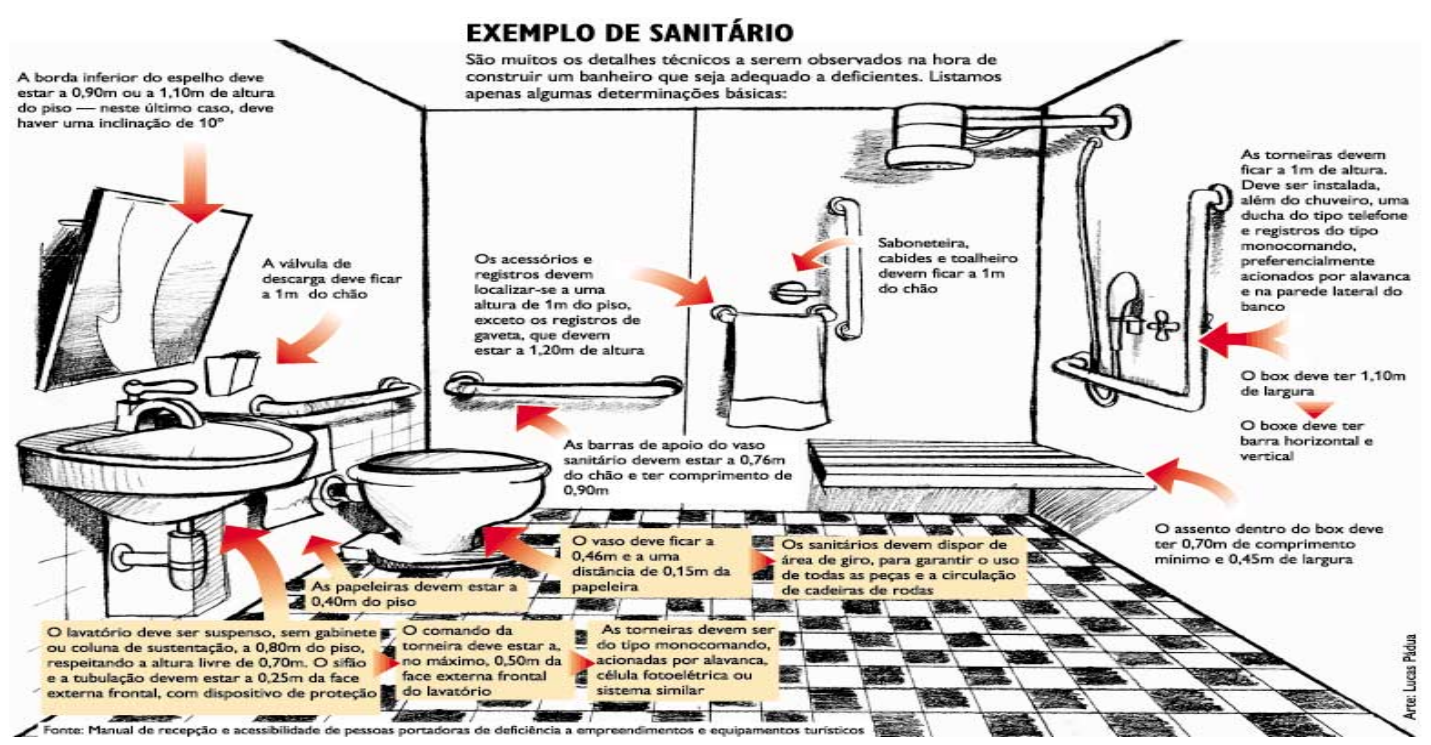



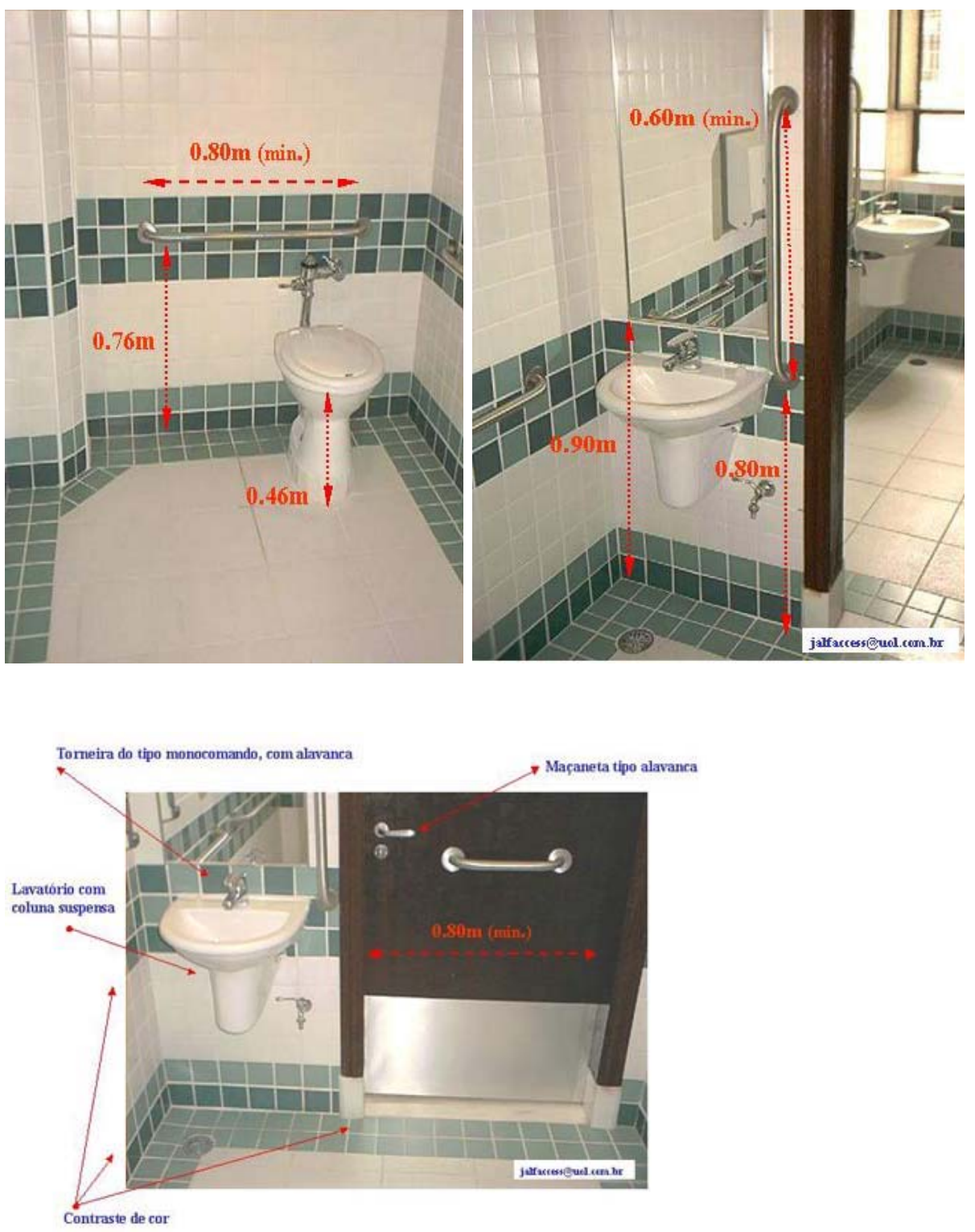

Na cozinha, é preciso planejar os balcões para que a cadeira de rodas possa se aproximar. A recomendação para a compra de móveis com, no máximo, $80 \mathrm{~cm}$ de altura, continua valendo. O armário deve estar a 1,20 de altura e a $30 \mathrm{~cm}$ de distância do piso.

Texto extraído da revista Sentidos de dezembro de 2001, uma publicação da Áurea Editora, colaboradora da Rede SACI. 
RAMPA - inclinação e altura das barras
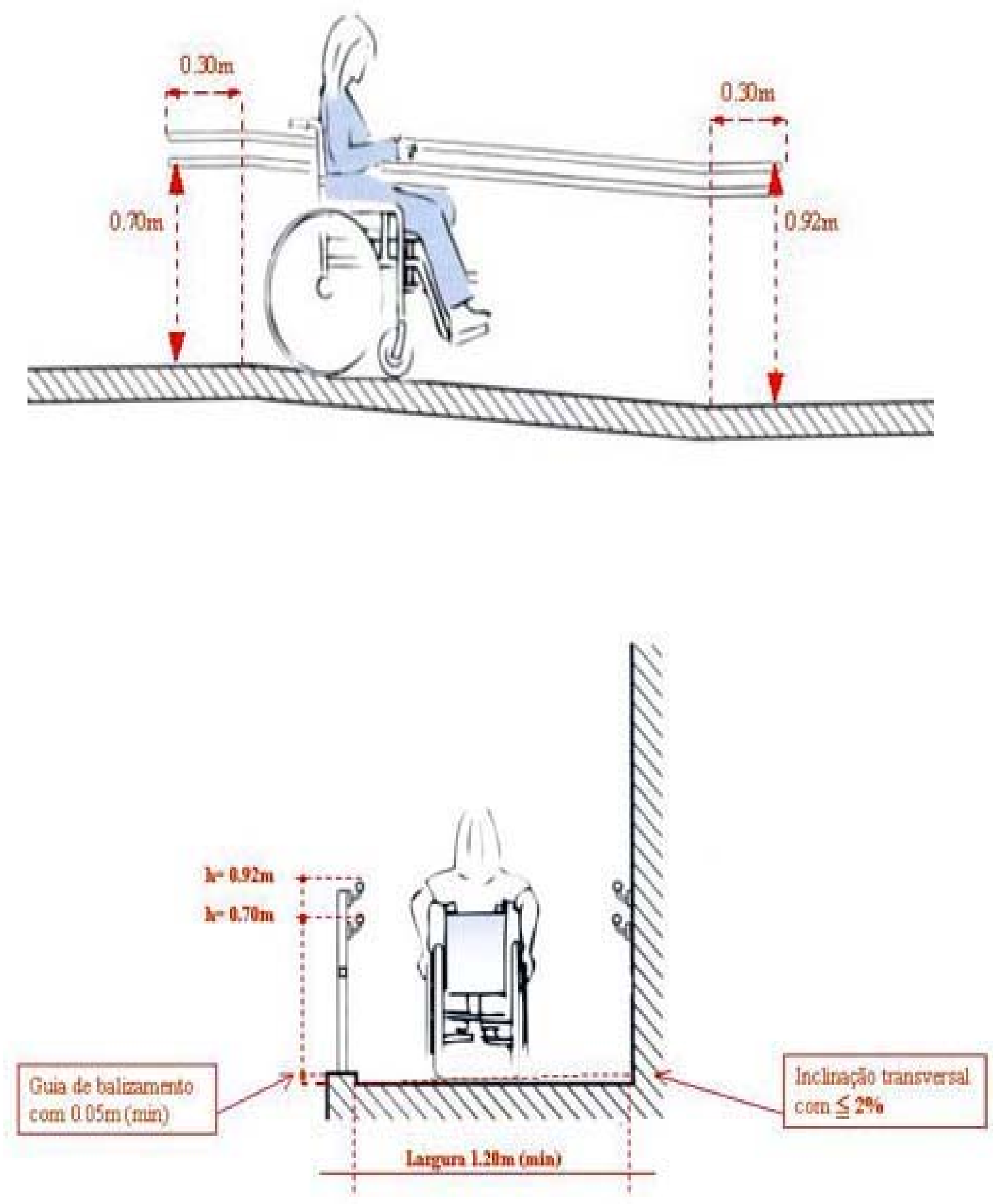
Uma vez adotadas essas providências, que são medidas consideradas de fácil execução e de custo relativamente e de aparato específico e que se configura como essencial para a evolução desses nichos os serviços turísticos tornar-se-ão democraticamente acessíveis a milhões de turistas brasileiros e do exterior, abrindo a possibilidade de ampliar o leque do fluxo turístico do país. 


\section{CAPÍTULO IV}

\section{4. ÁREAS DE HOSPEDAGEM E HOSPITALIDADE}

As mais diferentes pesquisas apontam que o principal diferencial do Brasil com relação ao Turismo é a sua diversidade de atrativos. O país possui características marcantes em todas as regiões, capazes de encantar qualquer turista. E, por isso, é importante que cada localidade, região ou estado saiba desenvolver e valorizar suas características próprias, criando diferenciais competitivos para que o turista sinta-se atraído e motivado a retornar àquela localidade, tendo em vista que muitas cidades oferecem os mesmos atrativos das cidades vizinhas como, por exemplo, as capitais do Nordeste, com seu roteiro sol e mar.

Toda diferença, seja em serviços prestados ou em novos roteiros, faz com que o turista mantenha seu encanto por determinado local por muito mais tempo e é esse encanto a base de sua viagem. Para que isso seja constante em todos os visitantes, faz-se necessário também, investimento em recursos humanos qualificados. Mas, acima disto, em conhecedores e estudiosos do Turismo capazes de qualificar e transmitir a esses profissionais a importância do seu papel neste conjunto. Têm-se então dois diferenciais: a educação e cultura.

Educar para poder transformar um simples atendimento em recordação inesquecível, para que cada profissional envolvido na área tenha consciência do seu valor, para que haja compreensão e respeito ao patrimônio histórico/cultural e ao meio ambiente. E, ensinando-os a amar e respeitar sua própria identidade cultural fica mais fácil de transmitir isto ao turista, envolvendo-o nesta magia, marcando sua passagem e, com certeza, recebendo-o novamente. E nisto, o papel do educador é fundamental, pois é ele quem vai acionar esta tecla no inconsciente de cada profissional. Este será nosso primeiro diferencial competitivo.

É fundamental, destacar que, para a execução do projeto em pauta, também é necessário uma formação de atitudes por parte do profissional do turismo, no sentido de estar preparado para as formas de ações com este segmento da sociedade. 
Da mesma forma temos cultura da hospitalidade. Se tomamos um dos seus significados, temos que o ato de ser hospitaleiro é uma característica marcante do nosso povo, mas como somente receber bem não basta, é necessário elevar o nível de qualidade dos serviços prestados. Aqui está o segundo diferencial - qualidade, fruto do primeiro - a capacitação.

A consciência de respeitar o que, é nossos, a valorização, o conhecimento, o bom desempenho e a responsabilidade de todos os profissionais da área de Turismo são algumas das palavras-chave que compõem a semente do fruto que estamos gerando: o desenvolvimento sustentável. Aprender, qualificar, planejar e desenvolver com os pés no presente, mas com a mente no futuro: este é o nosso objetivo. Desta forma, teremos um crescimento sadio do Turismo, com novos desafios e garantia de qualidade profissional e satisfação do cliente.

\subsection{Turismo, hospedagem e hospitalidade (REQUISITOS BÁSICOS)}

O profissional em turismo deve estar apto a atuar com ética e responsavelmente, no âmbito do setor hoteleiro como gestor e empreendedor no processo operacional do setor, garantindo a qualidade dos serviços e produtos oferecidos. Um profissional, versátil e empreendedor, para atuar, com ética e agilidade, nas empresas e empreendimentos hoteleiros e correlatos. Considerando a realidade social, econômica e cultural da cidade e da Região e as exigências do desenvolvimento com sustentabilidade, cumpre observar os desafios postos pelas mudanças organizacionais e avanços científico-tecnológicos.

Faz-se necessário a criação na sociedade de uma demanda por serviços de melhor qualidade, por meio da conscientização e mobilização quanto à importância de servir bem, ampliar a oferta de serviços de qualidade nessa área, por meio da formação de pessoas capazes de servir com competência.

Através de observação própria e participação em seminários, congressos e palestras foram destacados nesta monografia alguns problemas ainda existentes em Brasília. 


\subsubsection{HOSPEDAGEM}

* Falta de estrutura para receber o portador de necessidades especiais

* Funcionários não uniformizados

* Tratamento com restrições às pessoas portadoras com necessidades especiais e idosos.

* Dificuldades para obter crédito para o setor (juros altos etc.).

* Falta de orientação e sinalização de hotéis para os turistas (portais e para os centros informativos)

Inexistência de área de camping na região como hospedagem alternativa

Mão-de-obra pouco especializada

Falta de visão empresarial dos hoteleiros

\subsection{ALIMENTAÇÃO}

* Poucas casas de chá e cafeterias em toda região e casas de degustação de vinho;

* Pacotes de hotéis com refeições diminui a demanda dos restaurantes;

* Pouca qualificação de mão-de-obra (serviços e gerência);

Pacotes de hotéis inviabiliza roteiros de integração;

- Burocracia para financiamentos para melhoria e reforma de estabelecimentos (lanchonete, restaurantes, padaria);

* Insuficiência de placas (luminosos) do estabelecimento (restaurante, padaria, cafés);

- Horário reduzido de funcionamento dos restaurantes;

* Poucos restaurantes com comida típica; 
* Cuidado com higiene insuficiente em toda região (do espaço físico);

Precariedade nas instalações físicas dos restaurantes e apresentação dos mesmos.

\subsubsection{Serviços Turísticos}

Carência de treinamento de mão-de-obra em todos os níveis;

Destinação do lixo a céu aberto;

Carência de tratamento de água e esgoto;

Higienização precária nos setores em geral;

Despreparo de segurança pública em relação à demanda (fluxo) de turistas;

Eletricidade: custo elevado;

Inexistentes em algumas cidades (centros de informação);

* Carência de bancos 24 horas em alguns municípios;

* Carência de serviços médicos de urgência;

Número insuficiente de equipamentos e funcionários nos correios;

Não atendimento das solicitações de linhas telefônicas rurais;

Telefonia: custo elevado (móvel e fixa);

Aparelhos de retransmissão de TVs sucateados.

Perante este quadro ainda precário, a autora apresenta os principais tópicos que devem pautar a atuação do profissional do turismo, bem como sua contribuição para a priorização de ações e diretrizes no setor turístico de Brasília. Opções de hospedagens modernas e diversificadas, com atendimento de qualidade, produto honesto, com pacotes opcionais: 
Tabela 1

FONTE: A autora do trabalho. Maria Lúcia de Sá Cristofidis, 2003

\begin{tabular}{|c|c|c|}
\hline $\begin{array}{c}\text { Básico da Área de } \\
\text { Turismo e Hospitalidade }\end{array}$ & Alimentos e Bebidas & $\begin{array}{l}\text { Serviços em } \\
\text { Hospedagem }\end{array}$ \\
\hline $\begin{array}{l}\text { - Ética e trabalho; } \\
\text { - Fundamentos do turis- } \\
\text { mo e hospitalidade; } \\
\text { - Etiqueta social; } \\
\text { - Educação ambiental e } \\
\text { qualidade de vida; } \\
\text { - Comunicação e ex- } \\
\text { pressão; } \\
\text { - Saúde no trabalho e } \\
\text { primeiros socorros. }\end{array}$ & $\begin{array}{l}\text { - Manipulação; } \\
\text { - Processamento e con- } \\
\text { servação de alimentos; } \\
\text { - Planejamento e elabo- } \\
\text { ração de cardápios; } \\
\text { - Planejamentos das ins- } \\
\text { talações dos serviços } \\
\text { de alimentos e bebidas; } \\
\text { - Fundamentos dos ser- } \\
\text { viços de alimentos e } \\
\text { bebidas; } \\
\text { - Organização e supervi- } \\
\text { são de serviços de } \\
\text { alimentos e bebidas; } \\
\text { - Marketing e vendas de } \\
\text { produtos e serviços } \\
\text { gastronômicos. }\end{array}$ & $\begin{array}{l}\text { - Planejamento das insta- } \\
\text { lações dos serviços de } \\
\text { hospedagem; } \\
\text { - Organização e super- } \\
\text { visão dos serviços de } \\
\text { hospedagem; } \\
\text { - Gestão dos serviços de } \\
\text { hospedagem; } \\
\text { - Promoção e venda dos } \\
\text { serviços de hospe- } \\
\text { dagem. }\end{array}$ \\
\hline
\end{tabular}




\section{Tabela 2}

FONTE: A autora do trabalho. Maria Lúcia de Sá Cristofidis, 2003

\begin{tabular}{|l|l|}
\hline \multicolumn{1}{|c|}{ Ações/Diretrizes } & Prioridade \\
\hline $\begin{array}{l}\text { Normatizar o setor hoteleiro de forma a } \\
\text { atender também o portador de } \\
\text { necessidades especiais }\end{array}$ & alta \\
\hline $\begin{array}{l}\text { Sensibilizar e preparar o setor hoteleiro } \\
\text { para gestão ecologicamente correta }\end{array}$ & alta \\
\hline $\begin{array}{l}\text { Qualificar pessoal para atendimento } \\
\text { também ao portador de necessidades } \\
\text { especiais alta }\end{array}$ & \\
\hline $\begin{array}{l}\text { Dotar o setor hospedagem de infra- } \\
\text { estrutura e recursos humanos para } \\
\text { atendimento diferenciado - acordo com } \\
\text { público-alvo }\end{array}$ & alta \\
\hline Criar Centros de Informações Turísticas & \\
\hline $\begin{array}{l}\text { Orientar os empresários para } \\
\text { organização legal para elaborar projetos } \\
\text { viáveis para meios de obter linhas de } \\
\text { crédito. }\end{array}$ & média \\
\hline
\end{tabular}




\section{CAPÍTULO $v$}

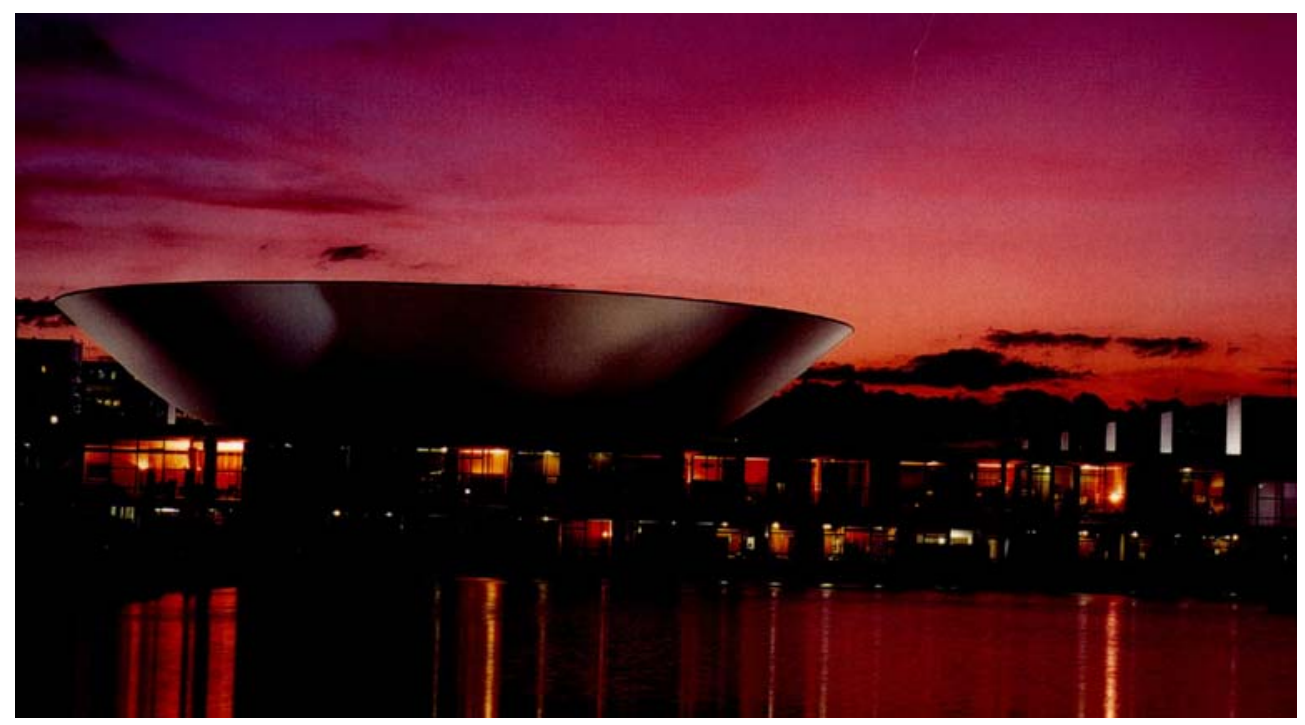

\section{CONHECENDO BRASÍLIA}

Vejo como relevante falar de Brasília por ser a capital do pais e por ser a cidade onde pretendo que seja desenvolvido a proposta em pauta. Brasília foi inaugurada e consagrada em 21 de abril de 1960 como Capital do Brasil e, nesse mesmo período, deu início ao processo de preservação com o próprio Presidente da República Juscelino Kubitscheck. O criador de Brasília mantinha uma preocupação constante, especialmente com o plano urbano e suas principais obras arquitetônicas.

Já em 1810, existia a proposta de fixação do governo no interior, longe dos portos, para garantir a segurança da capital do País. Entretanto, foi em,1891, com a promulgação da Primeira Constituição Republicana do Brasil, que surgiram as primeiras atitudes concretas, ao ser fixado, em seu artigo $3^{\circ}$ que seria demarcada, no Planalto Central, uma área de 14 mil quilômetros quadrados para a construção da futura capital. Em conseqüência, em 1892, foi nomeada a Comissão Exploradora do Planalto Central do Brasil, integrada por médicos, geólogos, botânicos, entre outros, e liderada pelo astrônomo Luiz Cruls, Cruls e seus companheiros, em apenas 7 meses, percorreram más de quatro mil quilômetros do Planalto Central Brasileiro. elaborando um levantamento minucioso sobre a topografia, o clima, a geologia, a flora, a fauna e os recursos materiais da região. A área ficou conhecida por 
Quadrilátero Cruls. Em 1894, o astrônomo apresentava ao Governo Republicano o "Relatório da Comissão Exploradora do Planalto Centra", o qual passou a ser conhecido por "Relatório Cruls".

Muitos anos se passaram até que a Constituição de 1946 determinasse novamente um estudo para a localização da nova capital, A Comissão nomeada em 1948. pelo então presidente Eurico Gaspar Dutra, conhecida como "Missão Polli Coelho", constatou, após 2 anos de trabalho, que o melhor local era, coincidentemente, o Quadrilátero Cruls. Somente em 1955, uma área de 50 mil quilômetros quadrados foi delimitada por determinação do presidente Café Filho, nascendo o atual Distrito Federal,Em abril de 1956, o presidente Juscelino Kubitschek de Oliveira deu início à instalação da Nova Capital, viajando pela primeira vez ao Planalto Central. juntamente com a equipe do urbanista Lúcio Costa. O grupo de arquitetos encabeçado por Oscar Niemeyer projetou, em curto espaço de tempo, todos os prédios públicos e grande parte dos residenciais A solução urbanística de Lúcio Costa partiu do traçado de dois eixos, cruzando-se em ângulo reto, como o sinal da cruz. Um deles, o Eixo Rodoviário, foi levemente arqueado para dar à cruz a forma de um avião, e as áreas residenciais do Plano Piloto foram chamadas de Asa Norte e Asa Sul. 0 corpo do avião tornou-se o Eixo Monumental, com 16 quilômetros de extensão, abrigando no lado leste os prédios públicos e palácios do Governo Federal: no centro, a Rodoviária e a Torre de TV, e no lado oeste, os prédios do Governo do Distrito Federal.

Brasília, nome sugerido já em 1823 por José Bonifácio, em memorial encaminhado à Assembléia Geral Constituinte do Império. foi inaugurada em 21 de abril de 1960, cento e cinqüenta anos após o então chanceler Veloso de Oliveira ter apresentado a idéia ao príncipe-regente. Anos mais tarde, em 1987, Brasília foi declarada pela Unesco Patrimônio Histórico e Cultural da Humanidade.

Brasília oferece grandes atrativos que a credenciam como promissor pólo de desenvolvimento sustentável: uma das rendas per capita mais altas do País, um grande esforço educacional, traduzido progressivamente na melhor capacitação de sua mão-de-obra - fator de maior qualidade e competitividade à empresa moderna e crescente consciência ambiental quanto à utilização não-predatória dos nossos 
recursos naturais. A adequada gestão ambiental de ocupações territoriais sempre foi um dos principais desafios do Poder Público.

Projetada para 500 mil habitantes, Brasília deparou-se, desde o início de sua construção, com elevadas taxas de crescimento populacional. Pólo de esperança e de atração para muitos brasileiros, o Distrito Federal hoje alcança população em torno de 1,8 milhão de habitante.

Brasília consolida-se, enfim, como marco na história da arquitetura e do urbanismo internacional figurando na lista do Patrimônio Mundial, deste 07 de dezembro de 1987, como primeiro monumento moderno do século XX.

Brasília foi tombada e inscrita no Livro de Tombo do Patrimônio Histórico e Artístico Nacional em 04 de março de 1990, com instituição da Portaria Regulamentadora no 04/90, alterada pela Portaria n 314, de 08 de outubro de 1992. Coube também à equipe que trabalhou junto com Lucio Costa e Oscar Niemeyer: 0 engenheiro Joaquim Cardozo, o paisagista Burle Marx, e artistas como Athos Bulcão, Alfredo Ceschiatti, Bruno Giorgi, entre outros.

\section{1- Brasília Capital de Todos}

Brasília nasceu do sonho de Dom Bosco e foi implantada graças a outro visionário, Juscelino Kubitschek. A idéia de construir uma cidade especificamente para ser a capital do País surpreendeu o mundo e despertou o interesse de muitos brasileiros que se mudaram para cá em busca de uma nova oportunidade. E, desde então, foi considerada um símbolo de modernidade e arrojo dos brasileiros.

Precisamos resgatar o orgulho de sermos brasilienses e mostrar ao Brasil e ao mundo Brasília como realmente é: a capital dos brasileiros, que está de braços e corações abertos para receber todos, possibilitando-lhes conhecer as inúmeras facetas de nossa cidade. Aqui há opções para todos os gostos, que valem a pena ser exploradas. 


\subsubsection{Brasília de todos nós}

Quem foi que disse que a Capital Federal não é uma cidade turística. É sim! E tanto que está buscando investir em eventos culturais e empresariais para atrair visitantes.

A cidade pode e deve ser percorrida e apreciada por todos nós, idosos, portadores de necessidades especiais, crianças e jovens.

A cidade está aberta a pessoas de todas as regiões do país, e a diversidade de costumes de seus habitantes vêm contribuindo para a definição da identidade cultural de Brasília.

\subsection{A Cidade}

O nível de acessibilidade do meio físico influencia largamente as necessidades específicas das pessoas com deficiência: um meio ambiente acessível reduz consideravelmente os problemas com que se deparam e, portanto, as necessidades. A grande maioria de pontos turísticos de Brasília dá acessibilidade a portadores de necessidades especiais, os quais podem perambular, ir e vir livremente sem barreiras, porém alguns ainda não estão adaptados para receber estas pessoas. É sugerido nesta monografia que seja observado essas questões de acessibilidade.

A seguir mostraremos pontos turísticos, culturais e de lazer, que encantam os turistas em qualquer categoria e opção turística a que pertencem Com uma única exceção, a Torre de TV, todos os outros locais mostrados têm acessibilidade para as pessoas portadoras de necessidades especiais. 


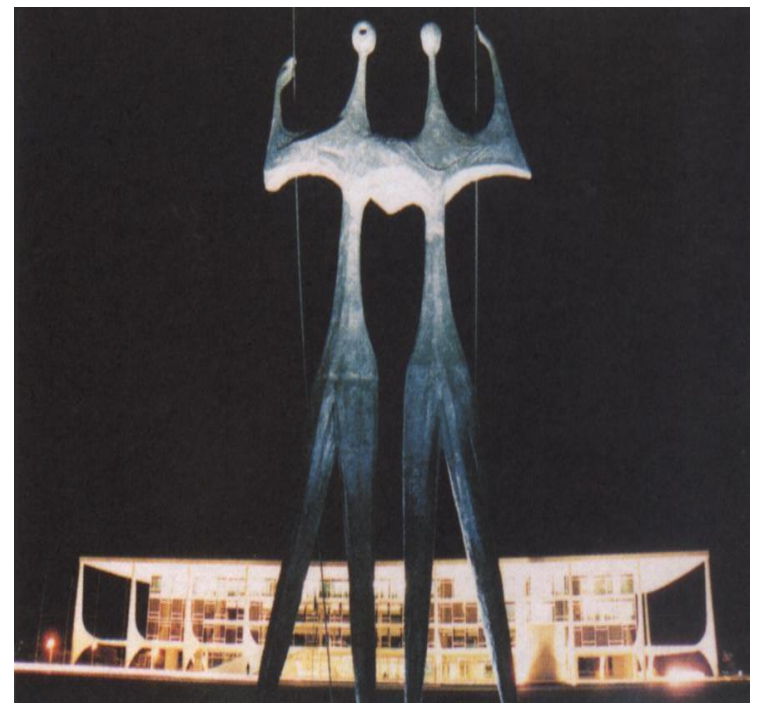

\subsubsection{Panorâmica Histórica E Cultural}

\section{PRAÇA DOS TRÊS PODERES}

End.: Eixo Monumental Leste

Linhas de ônibus: 108/104

Descrição: Idealizada por Lúcio Costa, e projetada por Oscar Niemeyer, é um amplo espaço que abriga os Poderes Executivo, Legislativo e Judiciário.

\section{MONUMENTOS, ESCULTURAS E MARCOS LOCALIZADOS NA PRAÇA DOS TRÊS PODERES:}

- Os Candangos: Escultura de Bruno Giorgi, de 1959, em bronze, com 8 metros de altura e considerada um dos símbolos da cidade.

- Pira da Pátria: Monumento de Oscar Niemeyer, em mármore e concreto, inaugurada em 21/4/87.

- A Justiça: Escultura de Alfredo Ceschiatti, de 1961, em granito de Petrópolis e pedra monolítica.

- Marco Brasília Patrimônio Cultural da Humanidade: Autoria de Oscar Niemeyer, inaugurado em 29/7/88, em homenagem ao ato da UNESCO que incluiu Brasília entre os bens culturais da humanidade.

- Cabeça de JK, em pedra-sabão, de J. Pedrosa.

- Cabeça de Israel Pinheiro: Escultura de Horácio Peçanha, em bronze 
- 0 Pombal: Escultura de Oscar Niemeyer, em concreto.

- Pavilhão Nacional: Monumento de autoria de Sérgio Bernardes, inaugurado em 1972. Trata-se de uma bandeira medindo 286 m que está a $100 \mathrm{~m}$ de altura. Seu mastro é formado por 24 hastes metálicas, que representam os estados da federação. A Solenidade da Troca da Bandeira é realizada a cada primeiro domingo do mês, sob a coordenação das Forças Armadas e do GDF

\section{ESPAÇO LÚCIO COSTA}

End: Praça dos Três Poderes - subsolo

Fone: 321.9843

Horário: De segunda a sexta, das $9 \mathrm{~h}$ às $18 \mathrm{~h}$ e sábados, domingos e feriados das $10 \mathrm{~h}$ às $18 \mathrm{~h}$

Linhas de ônibus: 108/104

Descrição: Obra de Oscar Niemeyer em homenagem a Lúcio Costa, é uma construção subterrânea que abriga a maquete de Brasília com 170 m2

\section{ESPAÇO OSCAR NIEMEYER}

End: Praça dos Três Poderes

Fone: 224.3255 HORÁRIO: De segunda a sexta, das $9 \mathrm{~h}$ às $12 \mathrm{~h}$ e das $14 \mathrm{~h}$ às $17 \mathrm{~h}$ Linhas de ônibus: 104

Descrição: localizada atrás da Praça dos Três Poderes, é um projeto próprio de Niemeyer, de linhas simples, em formato circular. Possui uma exposição permanente de painéis com fotos das suas obras, realizadas em Brasília e no mundo.

\section{SUPREMO TRIBUNAL FEDERAL}

End: Praça dos Três Poderes

Fones: 316.5891/316-5892

Horário: Dias de semana, mediante marcação prévia. Sábados e domingos, das 10h às 17h. Museu segunda a sexta, de $12 \mathrm{~h} 30$ às 18h

Linhas de ônibus: 108/104

Descrição: Projeto de Oscar Niemeyer, é sede do Poder Judiciário, tendo à sua frente a escultura "A Justiça", de Alfredo Ceschiatti. Possui biblioteca e museu. 


\section{PALÁCIO DA JUSTIÇA - MINISTÉRIO DA JUSTIÇA}

End: Esplanada dos Ministérios

Fones: $218.3223 / 3224$

Horário: De segunda a sexta, das $8 \mathrm{~h}$ às $12 \mathrm{~h}$ e das $14 \mathrm{~h}$ às $18 \mathrm{~h}$

Linhas de ônibus: 108

Descrição: Sede do Ministério da Justiça, destaca-se por sua fachada de lajes curvas entre arcos com cascatas artificiais que correm entre calhas de concreto.

\section{PALÁCIO DO ITAMARATY-MINISTÉRIO DAS RELAÇOES EXTERIORES}

End: Esplanada dos Ministérios

Fone: 411.6640

Horário: De segunda a sexta ,das 15h às 17h, e aos sábados, domingos e feriados, das $10 \mathrm{~h}$ às $14 \mathrm{~h}$

Linhas de ônibus: 108/104

Descrição: Projeto de Oscar Niemeyer, é a sede do Ministério das Relações Exteriores, também conhecido como Palácio dos Arcos. À sua frente, sobre a água, está o "Meteoro", obra de Bruno Giorgi formado por cinco blocos de mármore representando os cinco continentes. Possui jardins internos, várias obras de arte e sua decoração baseia-se no contraste entre o antigo e o moderno.

\section{PANTEÃO DA PÁTRIA}

End: Praça dos Três Poderes

Fone: 325.6244

Horário: De segunda a sexta, das $9 \mathrm{~h}$ às 18h, e aos sábados, domingos e feriados, das $10 \mathrm{~h}$ às $18 \mathrm{~h}$

Linhas de ônibus: 108/104

Descrição: Construído em memória do ex-Presidente Tancredo Neves e aos heróis da Pátria, sua forma sugere uma pomba. No "Salão Vermelho", um painel de Athos Bulcão, e no "Salão Principal", um painel histórico de João Câmara e vitral de Marianne Peretti. Projeto de Oscar Niemeyer.

\section{PLANETÁRIO}

End: Setor de Divulgação Cultural -Eixo Monumental Oeste 
Fone: 325.6245

Horário: (Fechado para reforma)

Linhas de ônibus: 131

Descrição: Com projeto de Sérgio Bernardes, tem a aparência de um disco voador, sua cúpula é de alumínio onde são projetados documentários sobre astronomia e meio ambiente.

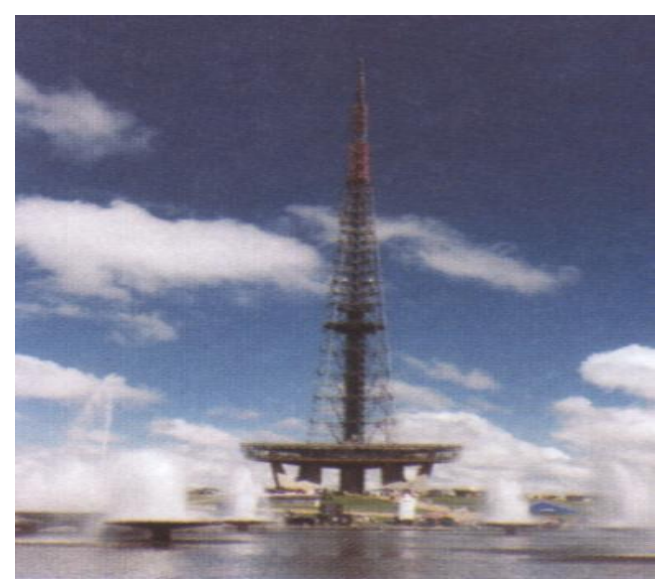

\section{TORRE DE TELEVISÃO}

\section{End.: Eixo Monumental Oeste}

Fone: 325.5735

Horário: segunda, das $14 \mathrm{~h}$ às20h, e de terça a domingo, das $8 \mathrm{~h}$ às $20 \mathrm{~h}$ Linhas de ônibus: 131

Descrição: Projeto de Lúcio Costa, com 224 m de altura é o centro irradiador de som e imagens das emissoras de rádio e TV. Aos 25 m funciona o Museu Nacional de Gemas; aos $75 \mathrm{~m}$, o mirante, com capacidade para 150 pessoas. À sua frente encontra-se a escultura "Era espacial" de Alexandre Wakenwit. Aos sábados, domingos e feriados funciona a tradicional Feira dos Artesanatos, das 8 às $18 \mathrm{~h}$. 


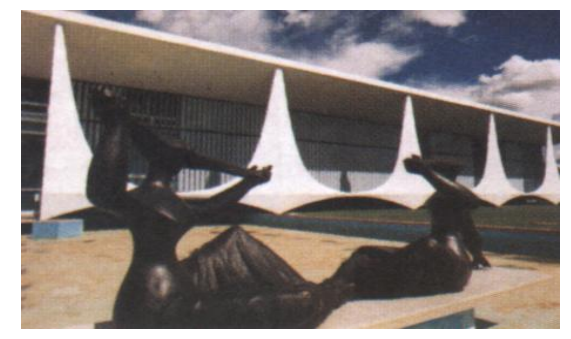

\section{PALÁCIO DO PLANALTO}

End: Praça dos Três Poderes

Fones: 411.1221/1355

Horário: Visitação externa, somente (escolas mediante agendamento antecipado) Linhas de ônibus: 108/104

Descrição: Inaugurado em 21/4/1960, abriga a sede do Poder Executivo. É também conhecido como Palácio dos Despachos. Projetado por Oscar Niemayer, que usou linhas curvas e retas com maestria e requinte. Todas as sextas-feiras às 17h30, realiza-se a cerimônia de arriamento da bandeira com a presença de bandas e Dragões da Independência.

\section{PALÁCIO DA ALVORADA}

End.: Setor de Hotéis e Turismo Norte

Fone: 411.4000

Horário: Visitação externa, somente

Linhas de ônibus: 104

Descrição: Localizado às margens do Lago Paranoá, é a residência oficial do Presidente da República. Suas colunas são o símbolo da cidade, utilizado em seu brasão. Projeto de Oscar Niemayer inaugurado em 30/6/1958. À frente do Palácio existem duas esculturas: "As lacas", de Ceschiatti, e "O Rio dos Ritmos", de Maria Martins. Ao lado, uma capela com fachada de Athos Bulcão. 


\section{PALÁCIO DO BURITI}

End.: Praça do Buriti - Eixo Monumental Oeste

Fone: 316.4111

Horário: Visitação externa, somente (temporariamente)

Linhas de ônibus: 131

Descrição: Projeto de Mauro Jorge Esteves, é sede do Governo do Distrito Federal e abriga o Gabinete do Governador e as Secretarias no edifício anexo. Foi inaugurado em 25/8/1969. Na frente do Palácio pode-se ver a réplica da Loba Romana, em bronze, doada ao Prefeito de Roma, e a escultura "Forma Espacial do Plano", de Ênio Liamini, doada pelo Presidente da Argentina à época, Jorge Rafael Videla.

\section{CONGRESSO NACIONAL}

End.: Praça dos Três Poderes

Fone: Câmara - 318.5107/ Senado: 311.3344

Horário: Câmara - de segunda a sexta, das $9 \mathrm{~h} 30$ às $12 \mathrm{~h}$ e das $14 \mathrm{~h} 30$ às $16 \mathrm{~h} 30$; sábados e domingos, das $9 \mathrm{~h}$ às $13 \mathrm{~h}$ (de hora em hora)

Horário: Senado - de segunda a sexta, das $9 \mathrm{~h}$ às $11 \mathrm{~h} 30$ e das $15 \mathrm{~h} 30$ às $16 \mathrm{~h} 30$; sábados e domingos, das 10h às 14h (de hora em hora)

Linhas de ônibus: 108/104

Descrição: Projetado por Oscar Niemayer é sede do Poder Legislativo. Os blocos em forma de $\mathrm{H}$ têm 28 andares e abrigam atividades administrativas. No seu interior, encontra-se vasto a cervo cultural e paisagístico. Nas cúpulas se localizam os plenários, a convexa da Câmara dos Deputados e a côncava do Senado Federal. Ao redor do edifício principal encontram-se os anexos de cada Casa e o Prodasen.

\section{ESPLANADA DOS MINISTÉRIOS}

End.: Eixo Monumental

Linhas de ônibus: 108/104

Descrição: Localizada no Eixo Monumental Leste, é um conjunto formado por 17 
edifícios distribuídos harmoniosamente e com regularidade arquitetônica.

\section{TEATRO NACIONAL CLÁUDIO SANTORO}

End.: Setor Cultural Norte, Via N2, em frente ao Conjunto Nacional Fone: 325.6105/6107/6250 - 325.6109 (bilheteria - a partir das 14h) Horário: Diariamente das $9 \mathrm{~h}$ às $20 \mathrm{~h}$

Descrição: Projeto de Oscar Niemeyer, tem a forma de uma pirâmide irregular, truncada no ápice. A fachada é uma composição plástica de cubos e retângulos de autoria de Athos Bulcão. Abriga três salas de espetáculos - Martins Penna (437), Villa Lobos (1307) e Alberto Nepomuceno (95). Foi inaugurado em 21 de abril de 1981. No hall vê-se as esculturas "Contorcionista", de Alfredo Cheschiatti, e "O Pássaro", de Marianne Peretti.

\section{SUPERIOR TRIBUNAL DE JUSTIÇA}

End.: Setor Administrativo Federal Sul, Q. 06, Lote 01

Fone: $319.6479 / 319.6798$

Horário: De segunda a sexta, horário comercial, preferencialmente pela manhã. Para grupos, é necessário marcação prévia

Linhas de ônibus: 108.3

Descrição: Setor da Corte de Justiça, Conjunto Arquitetônico idealizado por Oscar Niemayer. Constituído por 6 edifícios. É chamado de "prédio inteligente" pela alta e evoluída tecnologia empregada. Sua fachada dá visão diferente dos palácios de Justiça do Velho Mundo - uma fileira de colunas - uma floresta imaginária - curvas sinuosas e sensuais, visão mais moderna, que perde, um pouco, sua rigidez excessiva. 


\section{QUARTEL GENERAL DO EXÉRCITO}

End.: Setor Militar Urbano

Fone: 415.5151

Horário: Visitação somente na área externa

Linhas de ônibus: 109.1

Descrição: Projeto Arquitetônico de Oscar Niemayer e paisagístico de Burle Marx. É um conjunto de edifícios de linhas sóbrias, complementado por um Palanque Monumental, a Praça dos Cristais representando os cristais de rocha encontrados na região, o Oratório do Soldado, um Hotel de Trânsito com auditório.

\section{CENTRO POLIESPORTIVO AYRTON SENNA}

\section{End.: Eixo Monumental}

Fone:313.5900 (Secretaria de Esportes)

Horário: As quadras externas podem ser utilizadas a qualquer momento. Para os demais espaços, contatar a Secretaria de Esportes

Linhas de ônibus: 131/109

Nélson Descrição: Localizada no Eixo Monumental Oeste é um dos mais bem equipados complexos arquitetônicos do País, com o Estádio Mané Garrincha, o Ginásio de Esportes Nilson Nélson, pistas de atletismo, o conjunto aquático Cláudio Coutinho, quadras polivalentes, pista de bicicross e o Autódromo NELSON Piquet.

\section{CENTRO DE CONVENÇÕES ULISSES GUIMARÃES}

End.: SDC Eixo Monumental Oeste

Fone: 321.3318

Horário: De segunda a sexta, das $9 \mathrm{~h}$ às $19 \mathrm{~h}$

Linhas de ônibus: 131/109

Descrição: Localizado no Setor de Divulgação Cultural, projeto de Sérgio Bernardes. Possui 4 auditórios, sala VIP, diversas salas de apoio, 2 praças arborizadas, área para feiras e exposições e um restaurante. 


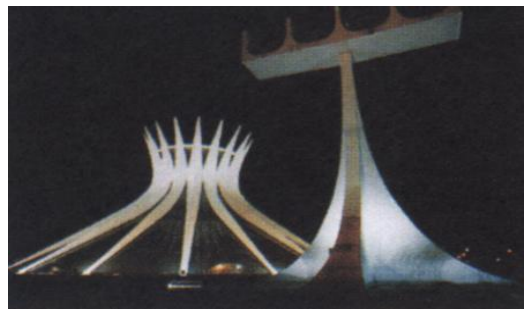

\section{CATEDRAL METROPOLITANA NOSSA SENHORA APARECIDA}

End.: Início da Esplanada dos Ministérios

Fone: 224.4073

Horário: Diariamente, das $8 \mathrm{~h}$ às $18 \mathrm{~h}$

Linhas de ônibus: 108/104

Descrição: Projetada por Oscar Niemayer, foi inaugurada em 31/5/1970. Possui 40 m de altura com 16 arcos de concreto armado circundados por um espelho d'água. $\mathrm{Na}$ área externa vêem-se os sinos que foram doados pelo Governo Espanhol, batizados com o nome de Santa Maria, Nina, Pinta e Pilarica. A cruz metálica de 12 $\mathrm{m}$ de altura no topo foi benzida pelo Papa Paulo VI. Na entrada, os quatro evangelistas: à direita, São João, a esquerda, São Mateus, São Lucas e São Marcos em bronze, medindo $3 \mathrm{~m}$ de altura, de Alfredo Cheschiatti. A entrada faz-se por uma área em declive de paredes negras tidas como zona de meditação. O interior é banhado por luz natural filtrado pelos vitrais coloridos de Marianne Peretti e lá vêemse a "Anunciação a Maria", de Athos Bulcão, a "Via-Sacra", de Di Cavalcanti, "Os Anjos", de Alfredo Cheschiatti, a primeira réplica de "Pietá", de Michelângelo, feita de mármore e resina, pesando 600 kg, doada por Paulo Xavier. Abaixo do Altar, réplica do Santo Sudário.

\section{ERMIDA DOM BOSCO}

End.: Às margens do Lago Paranoá - Após SHIS QI 29

Fone: 367.20000 (Instituto Israel Pinheiro)

Horário: 24h (espaço aberto)

Linhas de ônibus: 100/123 
Descrição: Pirâmide erguida em 1957, em homenagem a São João Bosco, localizase no ponto de passagem do paralelo 15 , referido na profecia.

\section{SANTUÁRIO DOM BOSCO}

End.: W3 Sul Q. 702

Fone: 223.6542

Horário: Diariamente, das $8 \mathrm{~h}$ às $18 \mathrm{~h}$

Linhas de ônibus: 107

Descrição: Projetado por Carlos Alberto Naves. São 80 colunas em "Brise-Soleil" com 16 m de altura fechando em estilo gótico, com vitrais em 12 tonalidades de azul, simbolizando um céu estrelado. No teto desenhos de Carlos Alberto Naves, o lustre central de Alvimar Moreira contém 7400 copos de vidros Murano e 180 lâmpadas pesando $2600 \mathrm{~kg}$. A cruz mede $8 \mathrm{~m}$, o Cristo de 4,30 m foi esculpido por Gotfredo Traller. A imagem encontrada à direita do altar é de Nossa Senhora Auxiliadora e à esquerda, de Dom Bosco. Suas portas em chapas de ferro e bronze, gravadas com os temas: o sonho profético e congregação de Dom Bosco, $1^{\text {a }}$ missa, Via-Sacra e próprio Santuário são do escultor Gian Franco Cerri.

\section{LBV - TEMPLO DA BOA VONTADE}

End:: SGAS 915 Lote 75/6

Fone: 245.1070

Horário: 24h (nave principal)

Linhas de ônibus: 105/107

Descrição: Projeto de RR. Roberto foi inaugurado em 21/10/89. O templo é composto por sete locais de visitação. A nave principal, uma pirâmide de sete faces que tem em seu ápice um cristal puro encontrado na região com $40 \mathrm{~cm}$ de altura e $21 \mathrm{~kg}$ e seu altar. Por ser um templo ecumênico, é representado apenas pelos 4 elementos da natureza (ar, água, fogo e terra); o salão nobre; a sala egípcia; 
a galeria de arte; Memorial Alziro Zarur (fundador da Legião); loja de souvenir e o Parlamundi, projetado para ser um centro Internacional de Eventos.

\section{IGREJA NOSSA SENHORA DE FÁTIMA - IGREJINHA}

End.: EQS 307/8

Fone: 242.0149

Horário: segunda, das $9 \mathrm{~h}$ às 21 h/ de terça a Sábado, das 6h às 20h/ Domingo das $6 h$ às $21 \mathrm{~h}$

Linhas de ônibus: 107

Descrição: Projetada por Oscar Niemayer, foi o primeiro templo de alvenaria inaugurado em Brasília, em 1958. Seu formato, bastante original, lembra o chapéu de freira. Seu interior foi decorado com azulejos de Athos Bulcão. Por ser bem pequena, ficou conhecida como Igrejinha.

\section{MUSEUS}

\section{MUS. VIVO DA MEMÓRIA CANDANGA}

End: Via EPIA Sul Lote D, HJKO - Núcleo Bandeirante.

Fones: $301.3590 / 3022$

Horário: De segunda a sexta das $9 \mathrm{~h}$ às $12 \mathrm{~h}$ e das $14 \mathrm{~h}$ às $18 \mathrm{~h}$

Linha de ônibus: 160

DESCRIÇAO: Construído em madeira tombado pelo Patrimônio Histórico e artístico do GDF em 1985, funciona no prédio do primeiro hospital de Brasília, o Hospital Juscelino Kubitschek (1957-1974). O museu desenvolve o programa Oficinas do saber Fazer e conserva peças do Brasília Palace Hotel e do próprio HJKO. Abriga o centro de referência do artesanato do DF. 


\section{MUS POSTAL E TELEGRÁFICO DA ECT}

End: SCS Ed. Apoio 0. 04 - Bloco A no 256

Fones: 317.1803 / 1802

Horário: De terça a sexta, das $9 \mathrm{~h}$ às $18 \mathrm{~h}$, sábado, das $9 \mathrm{~h}$ às $13 \mathrm{~h}$

Linha de ônibus: 107

Descrição: Expõe a retrospectiva histórica postal, telegráfica e telefônica nacional, desde os tempos da colônia. Diariamente, no horário do almoço, são apresentados filmes gratuitamente

MUS. CAIXA ECOMÔMICA FEDERAL

End: SBS 0. 04, Lote $3 / 4$ Anexo do Ed. Sede

Térreo - Conjunto Cultural da CEF

Fones: $414.9447 / 224.8856$

Horário: De terça a domingo e feriados, das $9 \mathrm{~h}$ às $19 \mathrm{~h}$

Linha de ônibus: 122

DESCRIÇÃO: O Edifício Cultural da CEF engloba um museu, uma pinacoteca, uma biblioteca e um auditório. O museu documenta aspectos interessantes da economia brasileira, desde a época do Império. Seu acervo é formado por mais de 10.000 peças e documentos que registram a história da própria instituição desde o século passado.

\section{MUS. DE GEOCIÊNCIA DA UnB}

End: Campus Universitário -Instituto de Geociências - ICC Centro Fone: $307.2438 / 34$

Horário: De segunda a sexta horário comercial. Para grupos, solicita-se marcação prévia

Linha de ônibus: 110

Descrição: 0 acervo inclui fósseis e algas marinhas encontradas no DF além de uma exposição de rochas, minerais, o pedaço de rocha mais antiga do mundo, com 3.900 
milhões de anos, encontrada no Canadá, além de um meteoro com 279 quilos, encontrado em um município de Goiás.

\section{MUS. DE ARTE DE BRASÍLIA}

End: Setor de Hotéis e Turismo Norte

Fones: 325.6242 / 6243

Horário: Fechado para reforma

Linha de ônibus: 104

Descrição: Criado com o intuito de divulgar a cultura brasileira e os movimentos culturais de Brasília, possui um acervo de mais de 700 obras representativas da arte brasileira dos últimos 30 anos e mantém um programa de exposições temporárias,

\section{Mus. HISTÓRICO DE BRASÍLIA}

End: Praça dos Três Poderes

Fone: 325.6244

Horário: De segunda a sexta ${ }^{\circ}$ das $9 \mathrm{~h}$ às $18 \mathrm{~h}$, e aos sábados, domingos e feriados, das $10 \mathrm{~h}$ às $18 \mathrm{~h}$

Linhas de ônibus: 108 / 104

Descrição: Projetado por Oscar Niemeyer, destaca-se por sua forma plástica. É o mais antigo de Brasília e foi inaugurado por JK no dia 21 de abril de 1960. Foi concebido para marcar a transferência da Capital do País para o Planalto e a conseqüente instalação do Governo Federal de Brasília. A história de Brasília é mostrada através de uma exposição de fotos.

\section{MEMORIAL JK}

End: Eixo Monumental Oeste

Fone: 225.9451

Horário: De terça a domingo das $9 \mathrm{~h}$ às $17 \mathrm{~h} 45$

Linha de ônibus: 131 
Descrição: Foi inaugurado em 1981. Em seu interior encontram-se a Sala das Metas, biblioteca de JK, com aproximadamente 3 mil volumes, uma sala de pesquisas, Auditório e exposição de fotos, medalhas, documentos e peças da construção de Brasília. Destaque para câmara mortuária no salão circular, onde estão os restos mortais do ex-presidente. Na área externa está o carro utilizado de Juscelino durante o seu mandato com presidente.

\section{Mus DO SUPREMO TRIBUNAL FEDERAL}

End: Praça dos Três Poderes Ed. Sede 39 andar Fones: 316.5110/ 316.5111

Horário: De segunda a sexta, das $13 \mathrm{~h}$ às 18h, sábado, domingo e feriados, das 10h às $17 \mathrm{~h}$

Linhas de ônibus: 108 / 104

Descrição: Seu objetivo é preservar a memória do Supremo Tribunal Federal. Possui peças do mobiliário do antigo Palácio da Suprema Corte no Rio de Janeiro. Em seu acervo destacam-se " A Justiça", escultura de H. Fruci, no plenário. A Galeria dos Ministros, composta por quadros dos ministros do Supremo, e um plenário construído em 1920.

\section{MUS. DA FUNDAÇÃO NACIONAL DE SAÚDE (SUCAM)}

End: SEPN 0.510 BL A Térreo

Fone: 273.7840

Horário: De segunda a sexta das $8 \mathrm{~h}$ às $12 \mathrm{~h}$ e das $14 \mathrm{~h}$ às $17 \mathrm{~h}$ (em reforma) Linha de ônibus: 116

Descrição: Conta com um acervo composto de cerca de 500 peças, que contam a história das técnicas usadas no combate às grandes endemias no Brasil.

\section{MUS. DO SENADO FEDERAL}


End: Praça dos Três Poderes - Congresso Nacional / Senado Federal Fones: 311.4029 / 311.4331

Horário: De segunda a sexta, das 9h30, as 11 h30 e das 14 h30 às 16h30, e aos sábados e domingos, das $10 \mathrm{~h}$ às $14 \mathrm{~h}$

Linhas de ônibus: 108 / 104

Descrição: Foi inaugurado em 1991, e conta a história do Senado, do Império à República.

\section{MUS. DE ARMAS}

End: Área Especial 01, Projeção L -Acad. Pol. Civil - Centro Adm. Taguatinga Fones: 371.3335 / 1321 HORÁRIO: De segunda a sexta,das 8h às 12h e das $14 \mathrm{~h}$ às $18 \mathrm{~h}$

Linha de ônibus: 306

Descrição: Foi inaugurado em 1994 e possui uma grande variedade de armas de valor histórico, coletadas em todo o território nacional.

\section{MUS. DE DROGAS}

End: Área Especial 01, Projeção L -Acad. I Civil- Centro Adm. Taguatinga Fone: 373 1321

Horário: De segunda a sexta, das $8 \mathrm{~h}$ às $12 \mathrm{~h}$ e das $14 \mathrm{H}$ às $18 \mathrm{~h}$

Linha de ônibus: 306

Descrição: Inaugurado em 1990, possui amostras de drogas e materiais apreendidos e tem por finalidade esclarecer o público sobre a prevenção do uso de drogas e suas conseqüências.

\section{MUS. DO SUPERIOR TRÍB. DE JUSTIÇA}

End: Setor Adm. Fed. Sul Q. 06 Lote 01 - Ed. dos Plenários 22 Pavimento Fones: $319.8151 / 53 / 54$

Horário: De segunda a sexta, das 9h às $18 \mathrm{~h}$ 
Linha de ônibus: 108,3

Descrição: Exibe fotos, documentos, mobiliário e testemunhos da trajetória do judiciário no País.

\section{MUS. DE ARTES 2: TRADIÇÕES DO NORDESTE}

End: Casa do Ceará - SGAN 0. 910 - Mod. F/G

Fone: 272.3833

Horário: De segunda a sexta das $8 \mathrm{~h}$ às $12 \mathrm{~h}$ e das $13 \mathrm{~h}$ às $17 \mathrm{~h}$ Linhas De Ônibus: 105 / 116

Descrição: Seu acervo contém 1.800 peças, divulgando costumes e tradições da cultura nordestina. Ocupa uma área de 30 mil metros quadrados.

\section{MUS. DO CATETINHO}

End: Rodovia BR $040 \mathrm{Km}$

Fones: 338,8694 1338-8807

Horário: Diariamente, das $9 \mathrm{~h}$ às $17 \mathrm{~h}$

Linhas de ônibus: 200/ 201

Descrição: Batizado em alusão ao Palácio do Catete no Rio de Janeiro, foi o primeiro projeto de Oscar Niemeyer para a cidade. Construído em apenas 10 dias com madeira da região, foi inaugurado em 10 de novembro de 1956 para ser a residência do então presidente Juscelino Kubitschek, quando da construção de Brasília. Guarda até hoje o mobiliário e os objetos pessoais e de trabalho do Presidente.

\section{MUS. DA ACADEMIA DA POLICIA FEDERAL}

End: Estrada Parque do Contorno Km 00 - Sobradinho Fone: 311.8885

Horário: De segunda a sexta das $8 \mathrm{~h} 30$ às $12 \mathrm{~h}$ e das $13 \mathrm{~h} 30$ às $17 \mathrm{~h}$

Descrição: Foi criado com o intuito de preservar a memória da corporação, conservando, para fins didáticos, instrumentos usados na prática e prevenção de 
crimes na área de entorpecentes.

\section{MUS. DE VALORES DO BANCO CENTRAL}

End: SBS 0. 03 Bloco B $1^{\circ}$ Subsolo Ed. Sede do Banco Central Fones: 414.2098/2519/2099

Horário: De segunda a sexta das $9 \mathrm{~h}$ às $17 \mathrm{~h} 30$, e aos sábados, das $14 \mathrm{~h}$ às $18 \mathrm{~h}$ Linha de ônibus: 122

Descrição: Possui acervo de 125 mil peças entre cédulas, moedas, condecorações, medalhas, e documentos de valores, além da numismática nacional. Ali está exposta a maior pepita de ouro já encontrada no Estado do Pará, no Garimpo de Serra Pelada, com 60 quilos. Conta ainda com a maior coleção de Portinari do mundo, abrigada em um só espaço e de outros artistas nacionais. Mostra a origem e a evolução do dinheiro no mundo, distribuídas nas salas Brasil, Moedas e Mundo.

\section{MUSEU DA IMPRENSA NACIONAL}

End: Setor de Indústrias Gráficas 0.06 Lote 800

Fone: 313.9618

Horário: De segunda a sexta das $8 \mathrm{~h}$ às $17 \mathrm{~h}$, e aos domingos e feriados, das $13 \mathrm{~h}$ às $18 \mathrm{~h}$

Linha de ônibus: 152

Descrição: Inaugurado em 13 de maio de 1982, com o objetivo de guardar, conservar e expor a memória da Indústria Gráfica da Imprensa Nacional do Brasil. Dedica-se também a pesquisas, sobretudo de caráter tecnológico, valorizando o aspecto artístico do trabalho gráfico oficial. Entre o acervo destacam-se um prelo de Machado de Assis, diários oficiais originais que publicaram a "Lei Áurea" em 1888 e o Ato da Proclamação da República em 1889. 


\section{MUS. DO TRABALHO}

End: Esplanada dos Ministérios Bloco F Térreo - Ed. Sede

Fone: 317.6724

Horário: De segunda a sexta das $8 \mathrm{~h}$ às $12 \mathrm{~h}$

Linha de ônibus: 108

Descrição: O seu acervo é formado por móveis, objetos pessoais, livros e peças que compõem uma réplica da sala onde trabalhava Lindolfo Collor, primeiro Ministro do Trabalho, Comércio e Indústria do Brasil.

\section{INSTITUTO HISTÓRICO E GEOGRÁFICO DO DF}

End: SEPS 703/903 Lote C/D/E

Fones: $226.7753 / 224.6544$

Horário: De segunda a sexta das $8 \mathrm{~h}$ às $12 \mathrm{~h}$ e das $14 \mathrm{~h}$ às $18 \mathrm{~h}$

Linhas de ônibus: 105 / 107

Descrição: Mantém uma exposição permanente sobre Brasília, Abriga também o Museu da Imagem e do Som e uma biblioteca especializada sobre o Distrito Federal.

\section{MUS. NACIONAL DE GEMAS}

End: Torre de Televisão - Salão Panorâmico Eixo Monumental Oeste Fone: 322.3227

Horário: De segunda a sexta, das 8 h30 às 20h30, e aos sábados e domingos, das 8 h30 às $18 h 30$

Linhas de ônibus: 131 / 109

Descrição: O local é destinado ao estudo, comercialização e apreciação de jóias, pedras e metais preciosos. 


\section{MUSEU BRASILEIRO DE CONTABILIDADE}

End: Prédio do Conselho Federal de Contabilidade SAS Quadra 05 Lote 03 Bloco J $-6^{\circ}$ andar

Fone: 314.9600

Horário: De segunda a sexta das $8 \mathrm{~h}$ às $12 \mathrm{~h}$ e das $13 \mathrm{~h} 30$ às $18 \mathrm{~h}$

Linha de ônibus: 114

Descrição: 0 museu está dividido em três momentos: a história da contabilidade através dos tempos, a história da contabilidade no Brasil e a última atuação do Conselho Federal de Contabilidade. Possui maquinário da área contábil, mobiliário original da época da Fundação CFC, na década de 1940.

\section{MUSEU DE SISMOLOGIA}

End: Observatório Sismológico - Campus da UnB

Fones: 349.4453 / 348.2145

Horário: De segunda a sexta horário comercial. Agendar com antecedência Linha de ônibus: 110

Descrição: Expõe modelos de placas tectônicas e vulcanismos, instrumentos de sismologias, fotos de terremotos catastróficos, entre outros e presta esclarecimentos sobre terremotos no Brasil e em outras regiões do mundo

\section{MUSEU DE TAXIDERMIA}

End: Centro Ecológico - Setor de Hípica It.08, em frente ao Jardim Zoológico Fone: 346.3825

Horário: segunda a sexta, das $8 \mathrm{~h}$ às $12 \mathrm{~h}$ e das $14 \mathrm{~h}$ às $17 \mathrm{~h}$

Linhas de ônibus: 160/ 162/ 118

Descrição: Exposição de animais empalhados da fauna silvestre e exótica, como aves, répteis, mamíferos e anfíbios, com objetivos educativos e científicos 


\section{MUSEU DA MEMORIA DA RODOVIÁRIA}

End: Mezanino da Rodoviária

Fone: 325.6243

Horário: De segunda a sexta das $9 \mathrm{~h}$ às $17 \mathrm{~h}$

Linhas de ônibus: Todas as linhas que atendem a Rodoviária

Descrição: Preserva os testemunhos da história do local desde a sua construção através de fotografias.

\section{MUSEU DA PREV. IR ASSISTÊNCIA SOCIAL}

End: SAS 0. 02 BL P - Térreo

Fones: $313.4816 / 4584$

Horário: De segunda a sexta, das $8 \mathrm{~h}$ às $18 \mathrm{~h}$

Linha de ônibus: 100

Descrição: Conta a história da Previdência através de bens materiais como por exemplo o primeiro processo de aposentadoria do país.

\section{MEMORIAL DOS POVOS INDÍGENAS}

End: Eixo Monumental Oeste - Praça do Buriti Fones: 223.3760/226.5206

Horário: De terça a sexta, de $9 \mathrm{~h}$ às $17 \mathrm{~h}$-sábados, domingos e feriados das $11 \mathrm{~h}$ às $17 \mathrm{~h}$.

Linha de ônibus: 131

Descrição: Preserva, pesquisa e divulga testemunhos da cultura indígena do Brasil, expõe coleção etnográfica de arte plumária, cerâmica, cestarias entre outras, coletadas por Darcy e Berta Ribeiro e por Eduardo Galvão. 


\section{MUSEU DA ACADEMIA DE POLÍCIA MILITAR}

End: Setor Policial Sul A/E 4 - APMDF

Fone: 245.4013

Horário: Fechado temporariamente para reestruturação

Linhas de ônibus: 154/ 153

Descrição: Inaugurado em 1995 a fim de preservar a história da Corporação, através de fotografias, insígnias, uniformes e equipamentos.

\section{MUSEU DA LIMPEZA URBANA}

End: QNP 28 - Usina do Lixo - A/E S/N

Fone: 376.1043

Horário: De segunda a sexta, das $8 \mathrm{~h}$ às $17 \mathrm{~h}$

Linha de ônibus: Linhas para o Setor "P" Sul

Descrição: Inaugurado em 1996, dá uma visão das possibilidades de reciclagem do lixo urbano. Conta com exposição de esculturas em sucata e objetos encontrados no lixo.

\section{MUSEU DA JUSTIÇA MILITAR DA UNIÃO}

End: SAS Ed. Sede do STM 2' andar Pça dos Tribunais Superiores Fone: 313.9223

Horário: De segunda a sexta, das $12 \mathrm{~h} 30 \mathrm{~h}$ às $18 \mathrm{~h} 30$

Linha de ônibus: 114

Descrição: Divulga a história e atuação do STM. Conta com uma exposição de telas, condecorações, mobiliário de época, uniformes. 
MUSEU DA JUSTIÇA ELEITORAL

End: SAS BL C Térreo - Pça dos Tribunais Superiores

Fone: $316.3440 / 08$

Horário: De segunda a sexta das 13h às 19h (P/ grupos ou horários especiais marcar com antecedência.)

Linha de ônibus: 114

Descrição: Divulga a história da Justiça Eleitoral do Brasil. Conta com uma exposição de urnas, títulos eleitorais, diplomas, mobiliário de época e fotos.

\section{MUSEU HISTÓRICO DO CORPO DE BOMBEIROS}

End: S.I.A. Tr. 04 It. 1520

Fone: 363.1120

Horário: De segunda a sexta das $9 \mathrm{~h}$ às $17 \mathrm{~h}$, exceto às quartas das $9 \mathrm{~h}$ às $13 \mathrm{~h}$ Linha de ônibus: 124

Descrição: Preserva a história da Corporação. Conta com uma exposição de fotografias, uniformes, insígnias, medalhas, equipamentos de combate a incêndio, .

\section{MUSEU HISTÓRICO E ARTÍSTICO DE BRAZLÂNDIA}

End: Rua do Lago Espelho d'Água - s/nº Centro

Fone: 391.1186 Ramal 92 (Div. Reg. de Ensino - SIEC)

Horário: De segunda a sexta, das $8 \mathrm{~h}$ às $17 \mathrm{~h}$

Linhas de ônibus: 400/404

Descrição: Preserva a história e a cultura local. Conta com uma exposição de fotografias, obras de artes plásticas e utensílios de época. 


\section{MUSEU DO CERRADO}

End: SAIN, Parque Rural, S/N ${ }^{\circ}$

Fone: 274.9608

Horário: De segunda a sexta de 7h30 às 10h30

Linha de ônibus: 128

Descrição: Plantas típicas do Cerrado, lagoa, jardim japonês e animais em extinção empalhados

\section{MUS. DA CÂMARA DOS DEPUTADOS}

End: Pça dos Três Poderes Ed. Sede da Câmara

Fones: 318.6801/ 6833

Horário: De segunda a sexta das 10h às 18h, e ao sábados, domingos e feriados das $9 \mathrm{~h}$ às $14 \mathrm{~h}$

Linhas de ônibus: 108/ 104

Descrição: Preserva a trajetória da Instituição. Conta com manuscritos, fotografias, mobiliários, filmes, vídeos. 


\subsection{2- PARQUES \& RECURSOS NATURAIS}

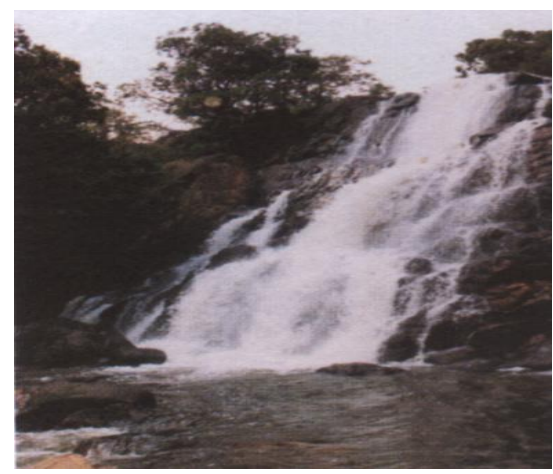

\section{PARQUE NACIONAL DE BRASÍLIA (AGUA MINERAL)}

Localização: Via EPIA BR-040 SMU

Fones: $233.4055 / 233.5322$

Horário: Diariamente das $8 \mathrm{~h}$ às $16 \mathrm{~h}$

Linha de ônibus: 128.1

Descrição: Unidade de Conservação Ambiental de nível federal com 30 mil hectares. Contém amostras significativas da fauna e da flora do Cerrado. 0 Parque possui um centro de visitantes e trilhas ecológicas. A área destinada à recreação possui excelente infra-estrutura, com destaque para o Parque Aquático, com duas piscinas de água mineral corrente. Cobra-se ingresso.

\section{JARDIM BOTÂNICO}

Localização: Setor de Mansões Dom Bosco Conj. 12 Lago Sul (Acesso pela 0123) Fone: 366.2141

Horário: De terça a domingo, das $9 \mathrm{~h}$ às $17 \mathrm{~h}$

Linha de ônibus: 147

Descrição: Possui 4.518 hectares, dos quais 526 abertos à visitação pública, é o maior Jardim Botânico de Savana do mundo. Possui uma trilha de $800 \mathrm{~m}$ de extensão que mostra ao visitante diversas formações do Cerrado. Mantém um horto medicinal de ervas naturais cultivadas e classificadas um centro de informações e 
mirante. Possui o jardim de cheiros do Cerrado. Cobra-se ingresso.

\section{JARDIM ZOOLÓGICO (Fund. Pólo Ecológico de Brasília)}

Localização: Av. das Nações - Saída Sul

Fone: 245.5003

Horário: De terça a domingo, das $9 \mathrm{~h}$ às $17 \mathrm{~h}$

Linhas de ônibus: 160/ 178.1/ 162

Descrição: Foi inaugurado em 6/12/57. Conta com mais de 1000 espécies representativas da fauna da América do Sul. Possui bar, lanchonete, restaurante, bosques para piquenique, teatro de arena com capacidade para 3000 pessoas, parque para crianças. 0 projeto atual é de Maruza Goretti. Cobra-se ingresso.

\section{PARQUE DA CIDADE - SARAH KUBITSCHEK}

Localização: Entrada e Saídas: Eixo Monumental 1 SIG/ SGAS W5 901/ 906/ 910 Fones: 225.2451 / 223.0702/ 325.1092

Horário: Diariamente, das $5 \mathrm{~h}$ às $24 \mathrm{~h}$

Linha de ônibus: 152 (SIG)/ 107(W3 Sul)

Descrição: Com 420 hectares, é a maior área de lazer da cidade. Oferece infraestrutura completa para recreação e atividades esportivas e sócio-culturais. Dispõe de restaurantes, anfiteatro, kartódromo, quadras polivalentes, duchas, ciclovia, bosque com churrasqueiras, parque infantil, centro hípico e a segunda maior área de exposição do Brasil, o EXPOBRASíLIA.

\section{LAGO PARANOÁ}

Localização: Circunda o lado leste da cidade de Brasília.

Descrição: Formado pelo represamento do Rio Paranoá e dos riachos Gama, Torto, Bananal, Fundo e Vicente Pires, com o objetivo de aumentar a umidade do ar e 
amenizar o clima seco da região, Possui $40 \mathrm{~km}^{2}$ de área, $80 \mathrm{~km}$ de perímetro. Permite a prática dos mais variados esportes náuticos e suas margens são destinadas a clubes, restaurantes e áreas de lazer (Projeto Orla).

\section{CACHOEIRA DO CÓRREGO CUPIM}

Localização: Área de Proteção Ambiental (APA de Cafuringa) Fone:500-0511

Acesso: Rodoviária pelo Eixo Monumental, sentido EPCL (Estrutural) até que se aviste a placa para Brazlândia à direita, seguir pela DF 001 até cruzar com a DF 240. Seguir pela DF 240 em direção a Padre Bernardo, seguir até encontrar DF 220, seguir.até.avistar.placas.indicativas.

Descrição: A área pertence aos monges católicos e vivem sobre as regras de São Columbanus. É formado por cursos de águas límpidas que correm sobre lajeados e degraus de pedras, criando seis cachoeiras e um salto, dois poços e diversas piscinas e duchas naturais. 0 relevo é bastante acidentado e a vegetação é típica do Cerrado.Visitas.mediante.reserva.

\section{PIPIRIPAU}

Localização: DF 410, Km 07 em frente à placa TAQUARA Acesso: Pela BR 020 até o km 19, no sentido Planaltina, onde entra-se à direita na DF 410 percorrendo $7 \mathrm{~km}$ de terra até a placa "Taquara". Seguir até a entrada da propriedade.

Descrição: Área formada pelo Córrego Pipiripau numa extensão de $100 \mathrm{~m}$, com várias cascatas formando uma piscina natural. 


\section{ESTAÇÃO ECOLÓGICA - ÁGUAS EMENDADAS}

Localização: BR-020, fica a 44 km de Brasília

Fone: 501-1791

Acesso: Pela BR-020, na região de Planaltina, entre as rodovias DF 17 e DF13 Descrição: É a mais importante reserva natural da região de Brasília. A água que brota de suas nascentes divide-se por causa de um desnível do terreno e alimenta cursos d'água que formam a Bacia Amazônica e Bacia do Prata . Engloba a Lagoa Bonita, única lagoa natural do DF Suas margens servem de abrigo para os animais silvestres. A fauna e flora ali preservadas constituem-se num laboratório vivo. É destinada a pesquisas e possui um centro de visitantes. É necessária permissão da SEMATEC para a realização das visitas .

\section{MORRO DO CENTENÁRIO}

Localização: Acesso pela BR-020, fica a $44 \mathrm{~km}$ de Brasília, próximo a Planaltina Descrição: Sua maior atração é a Pedra Fundamental, Patrimônio Histórico e Artístico Nacional, lançada em 1922, como um marco da mudança da Capital para o Planalto. O morro oferece uma bela vista das montanhas e vales que o circulam.

\section{SALTO DO TORORÓ}

Localização: DF 140 km 05

Acesso: 0123 do Lago Sul, em direção a Unaí. No trevo

pegar a DF-140, seguir $5 \mathrm{~km}$, entrar à direita, em estrada não asfaltada por mais 2 km, fica a 35 km de Brasília.

Descrição: Possui água limpa e cristalina com leito pedregoso e levemente acidentado. As trilhas que lhe dão acesso são ricas rochas de "quartzitos". O desnível é acentuado e a paisagem exuberante. 
POÇO AZUL

Localização:DF-001 km 105

Acesso: Pela Saída Norte até o balão do Posto Colorado, em direção a Brazlândia (DF-001), entrar no km 105

Fone: 982.4616

Descrição: 0 rio que percorre a Chapada da Vendinha, rompe uma rocha de quartzo e forma um grande poço de águas límpidas e azuladas, cascatas, corredeiras, cachoeiras e uma caverna inundada pelas águas. Fica em propriedade particular.

\section{CACHOEIRA E GRUTA DO RIO DO SAL}

Localização: DF 002 Km-19

Acesso: Saída Norte( BR 020 ), até o balão do Colorado, onde se deve seguir em direção a DF 001 até que se encontre a DF 170, neste ponto seguir pela DF 170 e depois pela DF 205 até a placa indicativa à direita, onde se lê Fazenda Babilônia. Fones: 391.1137/391.1139

Descrição: Vários patamares de pedras formando quedas de água que variam de 6 a 12 metros de altura, em uma distância média de 100 metros, formando piscinas naturais. A gruta possui várias galerias e salas cobertas de estalactítes e estalagmites de diversas cores e um grande salão com Visitas.mediante.reserva. cerca de $15 \mathrm{~m}$ de largura e $30 \mathrm{~m}$ de profundidade. Para visitas entrar primeiramente em contato com o proprietário.

\section{CACHOEIRA DE SAIA VELHA}

Localização: Saída Sul BR-040.

Acesso: Fica a 35 km de Brasília, BR-040, entrando à esquerda no Monumento "Solarium"

Fones: $627.0000 / 1627.6065$

Descrição: Área rica em vegetação e em cursos d'água, com várias quedas e 
piscinas naturais de água corrente. Saia Velha é aberta ao público e oferece infraestrutura.

\section{LAGOA BONITA OU MESTRE D'ARMAS}

Localização: Acesso pela BR-020, até a interseção com a DF-13. Após a entrada para Planaltina, entrar à esquerda e seguir $3 \mathrm{~km}$ por estrada não pavimentada. Possui $5 \mathrm{~km}$ de perímetro e aproximadamente $800 \mathrm{~m}$ de largura.

Descrição: Lagoa natural do DF. Suas margens servem de refúgio para os animais silvestres. Tem valor histórico, por ter marcado a passagem da Missão Cruls, em 1892.

\section{CHAPADA IMPERIAL}

Localização: Área de Proteção Ambiental (APA de Cafuringa)

Acesso: Eixo Monumental, sentido EPCL (Estrutural) até cruzar com a DF 001. Seguir no sentido Brazlândia. Adiante deixar a DF 001 e seguir pela DF 220 até a entrada da propriedade, que possui sinalização.

Fones: 345.8668 / 965.2461

Descrição: A maior reserva ambiental particular do DF. Possui várias cachoeiras e piscinas naturais de águas cristalinas. A propriedade possui declividade acentuada, formando fendas que vão dar em um canal por onde corre o Ribeirão Dois Irmãos. Os vales contêm ainda dezenas de afloramentos de rochas calcárias, com presença de cavernas. Visitas mediante reserva .

\section{CACHOEIRA DE SOBRADINHO}

Localização: Área de Proteção Ambiental (APA de São Bartolomeu) Acesso: Saída Norte, direção a Sobradinho. No balão do Colorado entrar à direita, pela DF 001 seguir até que encontre a DF 250. Seguir pela DF 250 até cruzar com a DF 330 pegando à esquerda seguindo até estrada vicinal, onde já se avista a 
cachoeira.

Descrição: Cachoeira formada pelo Ribeirão Sobradinho, formando uma volumosa queda, que resulta em uma cena de rara beleza. 


\section{CONCLUSÃO}

Numa sociedade de perfeitos ou do homem ideal, a pessoa portadora de necessidade especial é ainda ignorada e excluída restando, na maioria dos casos, confinada na própria família ou em uma instituição, como tradução da expressão "o que os olhos não vêem o coração não sente".

Atualmente, a "situação do portador de necessidades especiais numa sociedade urbana, pela forma como são desatendidas suas necessidades mais elementares, o transforma em vítima social".

a) a ausência de sensibilidade, não significa a ausência de sentimentos;

b) a incapacidade de movimentos, não significa uma pessoa incapaz;

c) a deficiência de um sentido, não quer significar uma vida sem sentidos.

A reversão deste quadro é lenta mas possível especialmente se, em todos os setores da sociedade, houver a gradativa conscientização de certos princípios éticos em relação as pessoas portadoras de necessidades especiais.

Esta monografia pretende destacar que, por sua característica de propiciar simultaneamente entretenimento e -------------, a atividade turística pode se tornar o espaço mais propício para que as pessoas portadoras de necessidades especiais se sinta um "igual" mediante o resgate de sua auto estima e a conquista de autonomia e de interação com o próximo no mundo do turismo.

Porque as diferenças não impedem ninguém de continuar a viver com dignidade, de desenvolver atividades, de sorrir de sonhar e de fazer turismo. As diferenças não impedem ninguém de voar

Como foi elaborada com base nos conceitos de inclusão social e igualdade de oportunidade, propôs ações afirmativas que possibilitem cada vez mais 
aperfeiçoar a qualidade dos serviços turísticos, está espelhada na maioria dos depoimentos selecionados.

Este trabalho, contudo trouxe a luz certas contradições históricas que ainda dominam a vida das pessoas portadoras de necessidades especiais: o seu cotidiano é ainda repleto de obstáculos, da acessibilidade e deslocamento ao grau ainda bastante alto de preconceito social.

Entretanto mesmo com certo tom visionário, demonstrou que o setor turístico em seus diferenciais de educação e cultura da hospitalidade, é o real setor de ação social e cidadania. E que, um dos ambientes mais propícios para esta ação de se alcançar o turismo sem barreiras é Brasília, a capital de todos.

A vontade política, a formação continuada dos profissionais de turismo, a importância de postura ética e das atitudes de compreensão e a aceitação das diferenças são alguns aspectos que podem humanizar este setor de economia em constante crescimento e mutabilidade.

A autora procurou apontar algumas alternativas que minimizem a instabilidade desta atividade econômica no Brasil e que valorizassem as pessoas portadoras de necessidades especiais em suas escolhas e preferências.

Finalmente, em par dessas considerações, a autora defende que seria de grande importância o desenvolvimento de cursos de capacitação sobre como atender a pessoas com necessidades especiais durante seus passeios turísticos. A formação de profissionais capacitados para o atendimento de portadores de deficiência deve atender a uma dupla perspectiva: o próprio desenvolvimento qualitativo do turismo em seu processo de expansão, e o conhecimento sobre as peculiaridades e condições dos portadores de necessidades especiais, como pessoa e não apenas como turista potencial. 


\section{REFERÊNCIAS BIBLIOGRÁFICAS}

ANDRADE, José Vicente. Turismo - fundamentos e dimensões. 8 ed. são Paulo, editora Ática, 1998.

BENI, Mário Carlos. Análise estrutural do turismo. 2 ed. São Paulo, editora SENAC, 1998.

BARRETTO, Margarita. Manual de iniciação ao estudo do turismo. 5 ed. CampinasSP, Papirus editora, 1995.

IGNARRA, Luiz Renato. Fundamentos do turismo. São Paulo, pioneira, 1999. . Turismo e legado cultural. Campinas-SP. Papirus editora, 2000.

FILHO, Américo Pellegrini. Ecologia, cultura e turismo. 2 ed. Campinas-SP. Papirus editora, 1997.

LEITE, José Romero Rodrigues. Turismo e segurança. 2 ed. Pernambuco, EMPETUR, 1987.

PAIVA, Maria das graças de Menezes V. sociologia do turismo. Campinas - SP, Papirus editora, 1995.

Turismo no Brasil - novos rumos. Site EMBRATUR: www.embratur.gov.br

VIEIRA, Juliana. A questão da educação profissional no âmbito do setor do turismo e da hospitalidade. Natal. UnP.

ZIMMERMANN, Adonis. Turismo rural - um modelo brasileiro. Florianópolis. Ed. Do autor, 1999.

GESTÃO DA INFORMAÇÃO - Prof. Antonio Flavio Testa. UnB. Brasília, 2003.

EDUCAÇÃO, TURISMO E HOSPITALIDADE: Cultura e Sociedade. Professora Maria Thereza Negrão de Melo. UnB. Brasília 2003.

EDUCAÇÃO TURISMO E HOSPITALIDADE: A Gastronomia no turismo e na hospitalidade. Professora Wilma Maria Coelho Araújo. UnB. Brasília, 2003.

TURISMO E HOSPITALIDADE: Representações e fenômenos mediáticos: Estratégias metodológicas para ensino e pesquisa. Professora Tânia Montoro. UnB. BRASÍLIA, 2003.

TEORIA DAS ORGANIZAÇõES. Professor Domingos Spezia. UnB. Brasília, 2003. 
GEOGRAFIA, TURISMO E MEIO AMBIENTE: Geografia do Turismo. Professor Rafael Sanzio Araújo dos Santos. UnB. Brasília, 2003.

ECONOMIA APLICADA AO TURISMO. Professor Jorge Arbache. UnB. Brasília, 2003. 
ANEXO 


\section{ANEXO I}

\section{EMBASAMENTO LEGAL}

Lei n. $^{\circ} \mathbf{6 5 1 3}$ de 20 de dezembro de $1977^{10}$

DISPÕE SOBRE A CRIAÇÃO DE ÁREAS ESPECIAIS E DE LOCAIS DE INTERESSE TURÍSTICO; SOBRE O INVENTÁRIO COM FINALIDADES DOS BENS DE VALOR CULTURAL E NATURAL; ACRESCENTA INCISO AO ART. $2^{\circ}$ DA LEI N. ${ }^{\circ}$ 4132, DE 10 DE SETEMBRO DE 1962; ALTERA A REDAÇÃO E ACRESCENTA DISPOSITIVO À LEI N. ${ }^{\circ}$ 4717, DE 29 DE JUNHO DE 1965 E DÁ OUTRAS PROVIDÊNCIAS.

O presidente da República.

Faço saber que o Congresso Nacional decreta e eu sanciono a seguinte Lei:

\section{CAPÍTULO I}

Das Áreas e dos Locais de Interesse Turístico

Artigo $1^{\circ}$ - Consideram-se de interesse turístico as Áreas Especiais e os Locais instituídos na forma da presente Lei, assim como os bens de valor cultural e natural, protegidos por legislação específica, e especialmente:

I - Os bens de valor histórico, artístico, arqueológico ou pré-histórico; II - as reservas e estações ecológicas;

III - as áreas destinadas à proteção dos recursos naturais renováveis;

IV - as manifestações culturais ou etnológicas e os locais onde ocorram;

V - as paisagens notáveis;

\footnotetext{
${ }^{10}$ Lei n. $^{\circ} 6513$ de 20 de dezembro de 1977. Lei de Acessibilidade.
} 
VI - as localidades e os acidentes naturais adequados ao repouso e a prática de atividades recreativas, desportivas ou de lazer;

VII - as fontes hidrominerais aproveitáveis;

VIII - as localidades que apresentam condições climáticas especiais;

IX - outros que venham a ser definido, na forma desta lei.

Artigo $2^{\circ}$ - Poderão ser instituídos, na forma e para os fins da presente Lei:

I - Áreas Especiais de Interesse Turístico;

II - Locais de Interesse Turístico.

Artigo $3^{\circ}$ - Áreas Especiais de Interesse Turístico são trechos contínuos do território nacional, inclusive suas águas territoriais, a serem preservadas e valorizadas no sentido cultural e natural, e realização de planos e projetos de desenvolvimento turístico.

Artigo $4^{\circ}$ - Locais de Interesse Turístico são trechos do território nacional, compreendidos ou não em Áreas Especiais, destinados por sua adequação ao desenvolvimento de atividades turísticas, e à realização de projetos específicos, e que compreendam:

I - bens não sujeitos a regime específico de proteção; II - os respectivos entorno de proteção e ambientação.

$\S 1^{\circ}$ - Entorno de proteção é o espaço físico necessário ao acesso do público ao Local de Interesse Turístico e à sua conservação, manutenção e valorização.

$\S 2^{\circ}$ - Entorno de ambientação é o espaço físico necessário à harmonização do Local de Interesse Turístico com a paisagem em que se situa. 
Artigo $5^{\circ}$ - A ação do Governo Federal, para a execução da presente Lei, desenvolver-se-á especialmente por intermédio dos seguintes órgãos e entidades:

I - Empresa Brasileira de Turismo - Embratur, vinculada ao Ministério da Indústria e do Comércio;

II - Instituto do Patrimônio Histórico e Artístico Nacional - IPHAN, do Ministério da Educação e Cultura;

III - Instituto Brasileiro de Desenvolvimento Florestal - IBDF, do Ministério da Agricultura;

IV - Secretaria Especial do Meio Ambiente - SEMA, do Ministério do Interior;

V - Comissão Nacional de Regiões Metropolitanas e Políticas Urbanas - CNPU, interministerial criado pelo Decreto n. ${ }^{\circ} 74.156$, de 6 de junho de 1974;

VI - Superintendência do Desenvolvimento da Pesca - SUDEPE, do Ministério da Agricultura.

Parágrafo Único - Sem prejuízo das atribuições que lhes confere a legislação específica os órgãos e entidades mencionados neste artigo atuarão em estreita colaboração, dentro das respectivas esfera de competência, para a execução desta Lei e dos atos normativos dela recorrentes.

Artigo $6^{\circ}$ - A Embratur implantará e manterá permanentemente atualizado o Inventário das Áreas Especiais de Interesse Turístico, dos Locais de Interesse Turístico e dos bens culturais e naturais protegidos por legislação específica.

$\S 1^{0}$ - A Embratur promoverá entendimentos com os demais órgãos e entidades mencionadas no art. $5^{\circ}$, com o objetivo de se definirem os bens culturais e naturais protegidos, que possam ter utilização turística, e os usos turísticos compatíveis com os mesmos bens. 
$\S 2{ }^{\circ}$ - Os órgãos e entidades mencionados nos incisos II A VI do art. $5^{\circ}$ enviarão à EMBRATUR, para fina de documentação e informação, cópia de todos os elementos à identificação dos bens culturais e naturais sob sua proteção, que possam ter uso turístico.

Artigo $7^{\circ}$ - Compete à EMBRATUR, realizar ad referendum do Conselho Nacional de Turismo - CNTur, as pesquisas, estudos e levantamentos necessários à declaração de Área Especial ou Local de Interesse Turístico:

I - de ofício;

II - por solicitação de órgãos da administração direta ou indireta, Federal, estadual, metropolitana ou municipal ou

III - por solicitação de qualquer interessado.

$\S 1^{\circ}$ - Em qualquer caso, compete à EMBRATUR determinar o espaço físico a analisar.

$\S 2^{\circ}$ - Nos casos em que os espaço físico a analisar contenha, no todo ou em parte, bens ou áreas sujeitos a regime específico de proteção os órgãos ou entidade nele diretamente interessados participarão obrigatoriamente das pesquisas, estudos e levantamentos a que se refere este serviço.

$\S 3^{\circ}$ - Serão ouvidos previamente o Serviço de Patrimônio da União - SPU, do Ministério da Fazenda, e o Instituto Brasileiro de Desenvolvimento Florestal - IBDF, do Ministério da Agricultura, sempre, sempre que o espaço físico a analisar contenha imóvel sob suas respectivas áreas de competência, constituindo-se, para o caso de bens do IBDF, o projeto de manejo dos parques e reservas a pré-condição à sua utilização para fins turísticos.

$\S 4^{\circ}$ - Quando o espaço físico a analisar estiver situado em área de fronteira, a EMBRATUR notificará previamente o Ministério das Relações Exteriores, para os fins cabíveis; no caso de áreas fronteiriças de potencial interesse turístico comum, a EMBRATUR, se o julgar conveniente, poderá também sugerir ao Ministério das 
Relações Exteriores a realização de gestões junto ao governo do país limítrofe, com vistas a uma possível ação coordenada deste em relação à parte situada em seu território.

Artigo $8^{\circ}$ - A EMBRATUR notificará os proprietários dos bens compreendidos no espaço físico a analisar do início das pesquisas, estudos e levantamentos.

$\S 1^{0}$ - Os proprietários dos bens referidos neste artigo ficarão, desde a notificação, responsáveis pela sua integridade, ressalvando-se:

I - a responsabilidade estabelecida por força da legislação federal específica de proteção do patrimônio natural e cultural;

Il - as obras necessárias à segurança, higiene e conservação dos bens, exigidas pelas autoridades competentes.

$\S 2^{\circ}$ - Serão igualmente notificadas as autoridades federais, estaduais, metropolitanas e municipais interessadas, para o fim de assegurar a observância das diretrizes a que se refere o $\S 4^{\circ}$.

$\S 3^{\circ}$ - As notificações a que se refere o presente artigo serão feitas:

I - diretamente aos proprietários, quando conhecidos;

II - diretamente aos órgãos e entidades mencionadas no parágrafo anterior, na pessoa de seus dirigentes;

III - em qualquer caso, por meio de publicação no Diário Oficial da União e nos dos Estados, nos quais estiver compreendido o espaço físico e analisar.

$\S 4^{\circ}$ - Das notificações a que se refere este artigo constarão diretrizes gerais provisórias para uso e ocupação do espaço físico, durante o período das pesquisas, estudos e levantamentos.

Artigo $9^{\circ}$ - Os efeitos das notificações cessarão: 
I - na data da publicação da resolução CNTur, nos casos de pronunciamento negativo;

II - 180(cento e oitenta) dias após a publicação da notificação no Diário Oficial da União, na ausência de pronunciamento do CNTur, dentro desse prazo;

III - 360 (trezentos e sessenta) dias após a publicação da notificação no Diário Oficial da União, caso não se tenha efetivado, até então, a declaração de Área Especial ou de Interesse Turístico.

Artigo $10^{\circ}$ - A EMBRATUR fica autorizada a firmar os convênios e contratos que se fizerem necessários à realização das pesquisas, estudos e levantamentos a que se refere o $\operatorname{art} .7^{\circ}$.

\section{CAPÍTULO II}

Das áreas Especiais de Interesse Turístico

Artigo $11^{\circ}$ - As Áreas Especiais de Interesse Turístico serão instituídas por decreto do Poder Executivo, mediante proposta do CNTur, para fins de elaboração e execução de planos e programas destinados a:

I - promover o desenvolvimento turístico;

II - assegurar a preservação e valorização do patrimônio cultural e natural;

III - estabelecer normas de uso e ocupação do solo;

IV - orientar a alocação de recursos e incentivos necessários a atender aos objetivos e diretrizes da presente Lei.

Artigo $12 .^{\circ}$ - As áreas Especiais de Interesse Turístico serão classificadas nas seguintes categorias: 
I - Prioritárias: áreas de alta potencialidade turística, que devam ou possam ser objeto de planos e programas de desenvolvimento turístico, em virtude de:

a) ocorrência ou iminência de expressivos fluxos de turistas e visitantes;

b) existência de infra-estrutura turística e urbana satisfatória, ou possibilidade de sua implementação;

c) necessidade da realização de planos e projetos de preservação ou recuperação dos locais de interesse turístico nelas incluídos;

d) realização presente ou iminente de obras públicas ou privadas, que permitam ou assegurem o acesso à área, ou a criação da infra-estrutura mencionada na alínea "b";

e) conveniência de prevenir ou corrigir eventuais distorções do uso do solo, causadas pela realização presente ou eminente de obras públicas ou privadas, ou pelo parcelamento e ocupação do solo.

II - de Reserva: áreas de elevada potencialidade turística, cujo aproveitamento deva ficar na dependência:

a) da implantação dos equipamentos de infra-estrutura indispensáveis;

b) da efetivação de medidas que assegurem a preservação do equilíbrio ambiental e a proteção ao patrimônio cultural ali existentes;

c) de providências que permitam regular, de maneira compatível com a alínea procedente, os fluxos de turistas e visitantes e as atividades, obras e serviços permissíveis.

Artigo $13 .^{\circ}$ - Do ato que declarar Área Especial de interesse turístico, da categoria prioritária, constarão:

I - seus limites; 
II - as principais características que Ihe conferirem potencialidade turística;

III - o prazo de formulação dos planos e programas que nela devam ser executados e os órgãos e entidades federais por eles responsáveis;

IV - as diretrizes gerais de uso e ocupação do solo que devam vigorar até a aprovação dos planos e programas, observada a competência específica dos órgãos e entidades mencionados no art.5\%;

V - as atividades, obras e serviço permissíveis, vedados ou sujeitos a parecer prévio, até a aprovação dos planos e programas, observando, observado o disposto no inciso anterior quanto à competência dos órgãos ali mencionados.

$\S 1^{0}$ Incluir-se-ão entre os responsáveis pela elaboração dos planos e programas, os órgão e entidades enumerados nos incisos II a VI do art. $5^{\circ}$, que tiverem interesse direto na área.

$\S 2^{\circ} \mathrm{O}$ prazo referido no inciso III poderá ser prorrogado, a juízo do Poder Executivo, até perfazer o limite máximo de 2 (dois) anos, contados da data de publicação do decreto que instituir a Área Especial de Interesse Turístico.

$\S 3^{\circ}$ - Respeitados o prazo previsto no ato declaratório e suas eventuais prorrogações, conforme o parágrafo anterior, compete ao CNTur aprovar, os prazos e programas ali referidos.

$\S 4^{\circ}$ - O decurso dos prazos previstos nos parágrafos anteriores, sem que os planos e programas tenham sido aprovados pelo CNTur, importará na caducidade da declaração de Área Especial de Interesse Turístico.

Artigo $14^{\circ}$ - A supervisão da elaboração e da implementação dos planos e programas caberá a uma comissão Técnica de Acompanhamento, constituída de representantes;

I - da EMBRATUR; 
II - dos demais órgãos e entidades referidos no artigo $5^{\circ}$

III - dos Governos estaduais e municipais interessados, e da respectiva região metropolitana, quando for o caso.

Artigo $15^{\circ}$ - Constarão obrigatoriamente dos planos e programas:

I - as normas que devam ser observadas, a critério dos órgãos referidos nos incisos II a VI, do artigo $5^{\circ}$, sob cuja jurisdição estiverem, a fim de assegurar a preservação, restauração, recuperação ou valorização, conforme o caso, do patrimônio cultural ou natural existente, e dos aspectos sociais que lhe forem próprios;

II - diretrizes de desenvolvimento urbano e de ocupação do solo, condicionadas aos objetos enumerados no inciso anterior e aos planos de desenvolvimento urbano e metropolitano que tenham sido aprovados pelos órgãos federais competentes;

III - indicação de recursos e fontes de financiamento disponíveis para implementação dos mesmos planos e programas.

Artigo $16 .^{\circ}$ - Os planos e programas aprovados serão encaminhados aos órgãos e entidades competente para sua implementação, nos níveis federais, estadual, metropolitano e municipal.

Artigo 17. - Do ato que declarar Área Especial de Interesse Turístico, da categoria de Reserva constarão:

I - seus limites;

II - as principais características que Ihe conferirem potencialidade turística;

III - os órgãos e entidades que devam participar da preservação dessas características;

IV - atividades, obras e serviços permissíveis, vedados ou sujeitos a parecer prévio. 
Parágrafo único - Os órgãos e entidades federais, estaduais, metropolitanos e municipais coordenar-se-ão com a EMBRATUR e com os órgãos mencionados no inciso III deste artigo, sempre que seus projetos, qualquer que seja sua natureza, possam implicar em alteração das características referidas no inciso II, deste artigo.

\section{CAPÍTULO III}

Dos Locais de Interesse Turístico

Artigo $18 .^{\circ}$ - Os locais de Interesse Turístico serão instituídos por resolução do CNTur, mediante proposta da EMBRATUR para fins de disciplina de seu uso e ocupação, preservação, proteção e ambientação.

Artigo 19. - As resoluções do CNTur, que declararem Locais de interesse Turístico, indicarão:

I - seus limites;

II - os entorno de proteção e ambientação;

III - os principais aspectos e características do Local;

IV - as normas gerais de uso e ocupação do Local, destinadas a preservar aqueles aspectos e características, e com eles harmonizar as edificações e construções, e a propiciar a ocupação e o uso do Local de forma com eles compatível.

\section{CAPÍTULO IV}

Da Ação dos Estados e Municípios

Artigo 20. - A EMBRATUR fica autorizada a firmar os convênios que se fizerem necessários, com os Governos estaduais e municipais interessados, para: 
I - execução, nos respectivos territórios, e no que for de sua competência, desta Lei e dos atos normativos dela decorrentes;

II - elaboração e execução dos planos e programas a que se referem os artigos 12 e seguintes;

III - compatibilização de sua ação, respeitando-se as respectivas esferas de competência e os interesses peculiares do Estado, dos Municípios e da região metropolitana interessados.

Parágrafo único - A EMBRATUR fica também autorizada a firmar convênios com órgãos e entidades federais, estaduais, metropolitanas e municipais visando à preservação do patrimônio cultural e natural, sempre com a participação do Instituto do Patrimônio Histórico e Artístico Nacional - IPHAN, respeitado o disposto no artigo $6^{\circ} \S 1^{\circ}$.

Artigo 21. - Poderão ser instituídas Áreas Especiais de Interesse Turístico e locais de interesse Turístico, complementarmente, a nível estadual, metropolitano ou municipal, nos termos da legislação própria, observadas as diretrizes fixadas na presente Lei.

Artigo 22. - Declarados, a nível federal, Área Especial de Interesse Turístico, ou Local de Interesse Turístico, os órgãos e entidades mencionados no artigo $5^{\circ}$ prestarão toda a assistência necessária aos Governos estaduais e municipais interessados, para compatibilização de sua legislação com as diretrizes, planos e programas decorrentes da presente Lei.

Artigo 23. ${ }^{\circ}$ - A EMBRATUR e os órgãos, entidades e agências federais que tenham programas de apoio à atividade turística darão prioridade, na concessão de quaisquer estímulos fiscais ou financeiros, aos Estados e Municípios que hajam compatibilizado sua legislação com a presente Lei, e aos empreendimentos neles localizados.

\section{CAPÍTULO V}




\section{Penalidades}

Artigo $24 .^{\circ}$ - Além da ação penal cabível, a modificação não autorizada, a destruição, a desfiguração, ou o desvirtuamento de sua feição original, no todo ou em parte, das Áreas Especiais de Interesse Turístico ou dos locais de Interesse Turístico, sujeitam o infrator às seguintes penalidades:

I - multa de valor equivalente a até 1.000 (mil) Obrigações Reajustáveis do Tesouro Nacional - ORTN;

II - interdição de atividade ou de utilização incompatível com os usos permissíveis das Áreas Especiais de Interesse Turístico ou dos Locais de Interesse Turístico;

III - embargo de obra;

IV - obrigação de reparar os danos que houver causado: restaurar o que houver danificado, reconstruir o que houver alterado ou desfigurado;

V - demolição de construção ou remoção de objeto que interfira com os entorno de proteção e ambientação do Local de Interesse Turístico.

Artigo $25 .^{\circ}$ - As penalidades referidas no artigo anterior serão aplicadas pela EMBRATUR.

§10- As penalidades dos incisos II a V, do art.24, poderão ser aplicadas cumulativamente com a do inciso I.

$\S 2^{\circ}$ - Caberá recurso ao CNTur.

I -"ex officio", nos casos de multa de valor superior a 100 (cem) Obrigações Reajustáveis do Tesouro Nacional - ORTN;

II - voluntário, sem efeito suspensivo, na forma e nos prazos a serem determinados por resolução do CNTur; 
$\S 3^{\circ}$ - Nos casos de bens culturais e naturais sob a proteção do IPHAN, do IBDF e da SEMA, aplicar-se-ão as penalidades constantes da respectiva legislação específica.

Artigo 26. - Aplicadas às penalidades dos incisos II a V, do art.24 a EMBRATUR comunicará o fato à autoridade competente, requisitando desta as providências necessárias, inclusive meios judiciais ou policiais, se for o caso, para efetivar a medida.

Artigo 27. - Quando o infrator for pessoa jurídica, as pessoas físicas que, de qualquer forma, houverem concorrido para a prática do ato punível na forma da presente Lei, ficam igualmente sujeitas às penalidades do art.24, inciso I.

Artigo 28. - O produto das multas constituirá renda própria do órgão que houver aplicado a penalidade.

\section{CAPÍTULO VI}

\section{Disposições Finais}

Artigo 29. - Dos instrumentos de alienação de imóveis situados em Áreas Especiais de Interesse Turístico, ou em locais de Interesse Turístico, constará obrigatoriamente, sob pena de nulidade, o respectivo ato declaratório, ainda que por meio de referência.

Artigo $300^{\circ}$ - Órgãos e entidades da Administração Direta ou Indireta, federal, estadual, metropolitana ou municipal, compatibilizarão os planos, programas e projetos de investimentos, que devam realizar em Áreas Especiais de Interesse Turístico ou em Locais de Interesse Turístico, com os dispositivos e diretrizes da presente Lei ou dela decorrentes.

Parágrafo único - A aprovação de planos e projetos submetidos aos órgãos, entidades e agências governamentais, e que devam realizar-se em Áreas Especiais de Interesse Turístico, será condicionada à verificação da conformidade dos 
referidos planos e projetos com as diretrizes da presente Lei e com os atos dela decorrentes.

Artigo $31 .^{\circ}$ - O Art. $2^{\circ}$, da Lei n. ${ }^{\circ} 4132$, de 10 de setembro de 1962, passa a vigorar acrescido do inciso seguinte:

"Art. $2^{\circ}$

VIII - a utilização de áreas, locais ou bens que, por suas características, sejam apropriados ao desenvolvimento de atividades turísticas".

Artigo 32. - A EMBRATUR promoverá as desapropriações e servidões administrativas decretadas pelo Poder Executivo, com fundamento no interesse turístico.

Artigo $33 .^{\circ}$ - O $\S 1^{\circ}$, do art. $^{\circ}$, da Lei 4717, de 29 de junho 1965, passa a ter a seguinte redação:

Artigo $34 .^{\circ}$ - O art.5º da Lei n. ${ }^{\circ}$ 4717, de 29 de junho de 1965, passa a vigorar acrescido do seguinte parágrafo:

"Art.50

$\S 4^{0}$ - Na defesa do patrimônio público caberá a suspensão liminar do ato lisivo impugnado".

"Art.1

$\S 1^{\circ}$ - Consideram-se patrimônio público para os fins referidos neste artigo, os bens e direitos de valor econômico, artísticos, estéticos, históricos ou turísticos".

Artigo 35. - O Poder Executivo no prazo ativo regulamentará a presente Lei no prazo de 180 (cento e oitenta) dias, a contar da data de sua publicação. ${ }^{1}$

Artigo 36. - A presente Lei entrará em vigor na data de sua publicação.

Artigo 37. - Revogam-se as disposições em contrário. 
Origem: Brasil Poder Legislativo

Tipo: Lei

Num: 006513

Data: $20 / 12 / 1977$

Fonte: Pub.DOFC 22/12/1977 0176681

Texto: Dispõe sobre a criação de áreas especiais e de locais de interesse turístico sobre o inventário com finalidades turística dos bens de valor cultural e natural, acrescenta inciso ao artigo 2 da Lei n. ${ }^{0} 4.132$ de 10/09/1962, altera a redação e acrescenta inciso ao artigo 2 da Lei n. ${ }^{0} 4.717$ de 29/06/1965, e dá outras providências

VIDE: Dec/086176/1981 DOFC 07/07/1981 012537 Regulamentação; Prt/000021/1979 DOFC 30/01/1979 0014511 Regulamentação. 
RESUMO: TURISMO EM BRASÍLIA PARA PORTADORES DE NECESSIDADES ESPECIAIS.

Este trabalho faz uma abordagem à necessidade de acessibilidade ao turismo no DF para pessoas portadoras de necessidades especiais. O trabalho esta desenvolvido pelo turismo no exercício da cidadania pelo portador de necessidades especiais. Dentro dessa premissa, procurou desenvolver atividades relacionadas ao turismo de Brasília. Objetiva-se proporcionar ao portador de necessidades especiais um suporte, para que ele se sinta parte de uma sociedade que saiba respeitar as limitações de cada um. É nessa perspectiva que este trabalho apresenta o projeto, cujo objetivo é sensibilizar e conscientizar a população o poder público bem como os setores envolvidos com turismo, para a atuação nessa área, mobilizando, assim, todos na busca de uma vida sem barreiras. Mostrando que é possível adaptar os espaços já edificados ou por edificar e adequar os transportes públicos para que todas as pessoas, independentemente de suas diferenças, possam desempenhar atividades simples e habituais que permeiam a vida dos cidadãos turistas, como se locomover com segurança e liberdade, comunicar-se com facilidade, ou seja, viver com dignidade, autonomia e independência. . A obra explora a trajetória de quem luta pela igualdade e direitos dos portadores de necessidades especiais perante a sociedade. 
SUMMARY: TOURISM EM BRASÍLIA ABOUT TO BEARERS OF NECESSITIES SPECIAL.

This paper makes an approach to the accessibility need to the tourism in DF for people with any kind of disability. The subject has been developed by the tourism under citizenship principles for the above mentioned ones. Along these lines, to develop activities related to the tourism of Brasília. It is aimed to provide a support to the handicapped, so that they feel part of a society that knows how to respect everyone's limits. The differences don't hinder anybody of flying. It is in that perspective that this work presents the project, which objective is to sensitize and to call the population's attention, the government as well as the tourism sections, for the performance in this area, mobilizing, therefore, everyone in the search of a life without hindrance. Showing that is possible to adapt areas already built or to be built and to adapt the public transportations so that all the people, no matter their differences, can carry simple activities out that can happen to any citizens doing tourism. For instance, moving around with safety and freedom, communicating freely, in other words, to live with dignity, autonomy and independence. This paper explores the path of those who struggles for equality and rights of the handicapped before the society. 


\section{SUMÁRIO}

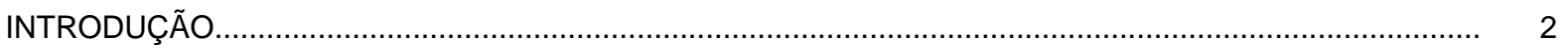

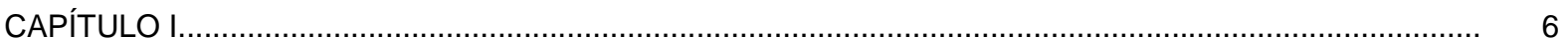

1. HISTÓRICO

1.1. Conceito de Turismo

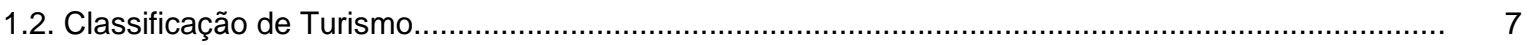

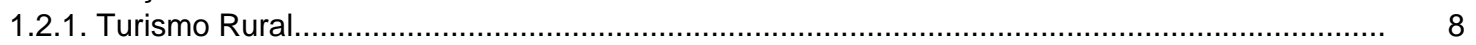

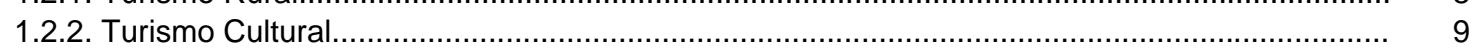

1.2.3. Turismo Ecológico.............................................................................................. 10

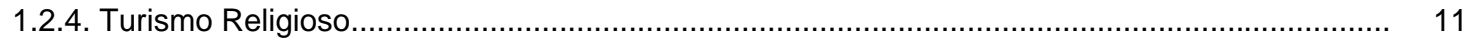

1.2.5. Turismo de Negócios.............................................................................................. 12

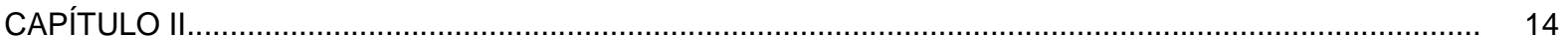

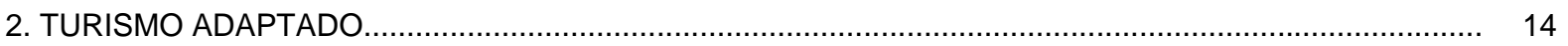

2.1. Depoimentos e Entrevistas............................................................................................... 15

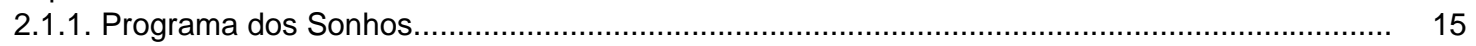

2.1.2. Depoimentos de Pessoas Portadoras de Necessidades Especiais......................................... 16

2.1.3. Entrevistas com Pessoas Portadoras de Necessidades Especiais Moradoras de Brasília........ 26

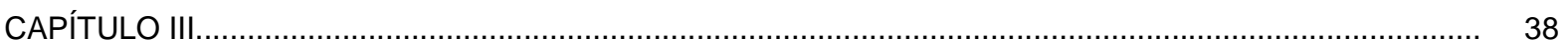

3. Turismo e Acessibilidade .........................................................................................................

3.1. Analisando o Profissional do Turismo .................................................................................... 38

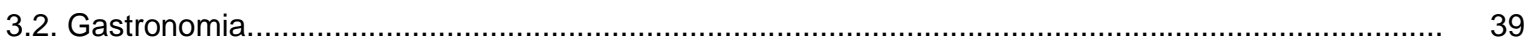

3.2.1. Comida de Branco......................................................................................... 41

3.3. A Melhor Idade e Portadores de Necessidades Especiais............................................................. $\quad 42$

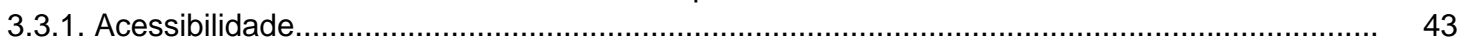

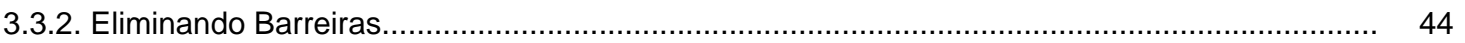

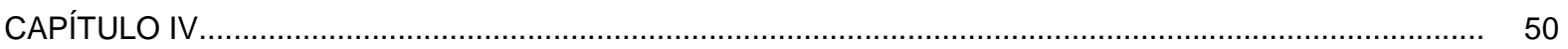

4. ÁREAS DE HOSPEDAGEM E HOSPITALIDADE...................................................................... 50

4.1. Turismo, Hospedagem e Hospitalidade (Requisitos Básicos)..................................................... 51

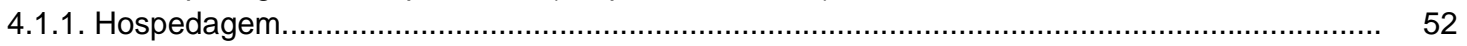

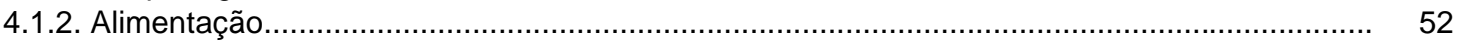

4 1.3. Serviços Turísticos................................................................................................... 53

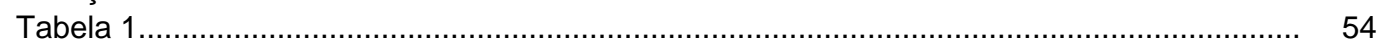

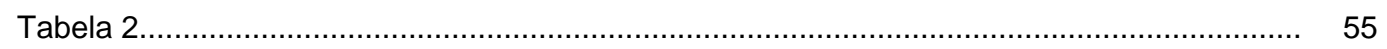

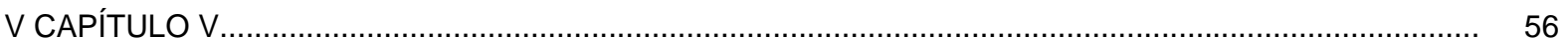

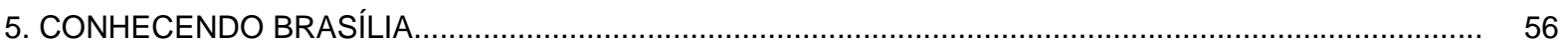

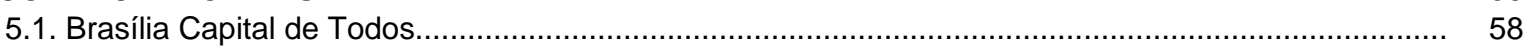

5.1.1. Brasília de Todos Nós............................................................................................. 59

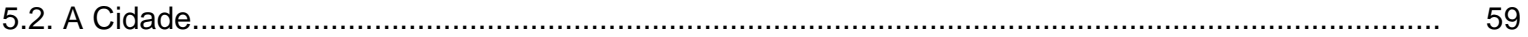

CONCLUSÃO

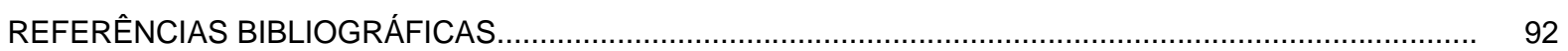

ANEXO 